Article

\title{
Synthesis, Biological Activity and Molecular Docking Studies of Novel Nicotinic Acid Derivatives
}

\author{
Kinga Paruch 1,*(D), Anna Biernasiuk ${ }^{2} \mathbb{D}$, Dmytro Khylyuk ${ }^{1} \mathbb{D}$, Roman Paduch ${ }^{3} \mathbb{D}_{\text {, Monika Wujec }}{ }^{1}$ (D) \\ and Łukasz Popiołek ${ }^{1}$
}

1 Chair and Department of Organic Chemistry, Faculty of Pharmacy, Medical University of Lublin, 4A Chodźki Street, 20-093 Lublin, Poland; dmytro.khylyuk@umlub.pl (D.K.); monika.wujec@umlub.pl (M.W.); lukasz.popiolek@umlub.pl (Ł.P.)

2 Chair and Department of Pharmaceutical Microbiology, Faculty of Pharmacy, Medical University of Lublin, 1 Chodźki Street, 20-093 Lublin, Poland; anna.biernasiuk@umlub.pl

3 Department of Virology and Immunology, Institute of Biological Sciences, Faculty of Biology and Biotechnology, Maria Curie-Skłodowska University, 19 Akademicka Street, 20-033 Lublin, Poland; rpaduch@poczta.umcs.lublin.pl

* Correspondence: kinga.paruch@umlub.pl

Citation: Paruch, K.; Biernasiuk, A.; Khylyuk, D.; Paduch, R.; Wujec, M.; Popiołek, Ł. Synthesis, Biological Activity and Molecular Docking Studies of Novel Nicotinic Acid Derivatives. Int. J. Mol. Sci. 2022, 23, 2823. https://doi.org/10.3390/ ijms 23052823

Academic Editor: Andrea Pace

Received: 4 February 2022

Accepted: 24 February 2022

Published: 4 March 2022

Publisher's Note: MDPI stays neutral with regard to jurisdictional claims in published maps and institutional affiliations.

Copyright: (C) 2022 by the authors. Licensee MDPI, Basel, Switzerland. This article is an open access article distributed under the terms and conditions of the Creative Commons Attribution (CC BY) license (https:// creativecommons.org/licenses/by/ $4.0 /)$.

\begin{abstract}
In our research, we used nicotinic acid as a starting compound, which was subjected to a series of condensation reactions with appropriate aldehydes. As a result of these reactions, we were able to obtain a series of twelve acylhydrazones, two of which showed promising activity against Gram-positive bacteria (MIC $=1.95-15.62 \mu \mathrm{g} / \mathrm{mL}$ ), especially against Staphylococcus epidermidis ATCC 12228 (MIC $=1.95 \mu \mathrm{g} / \mathrm{mL}$ ). Moreover, the activity of compound $\mathbf{1 3}$ against the Staphylococcus aureus ATCC 43300 strain, i.e., the MRSA strain, was MIC $=7.81 \mu \mathrm{g} / \mathrm{mL}$. Then, we subjected the entire series of acylhydrazones to a cyclization reaction in the acetic anhydride, thanks to which we were able to obtain twelve new 3-acetyl-2,5-disubstituted-1,3,4-oxadiazoline derivatives. Obtained 1,3,4-oxadiazolines were also tested for antimicrobial activity. The results showed high activity of compound 25 with a 5-nitrofuran substituent, which was active against all tested strains. The most promising activity of this compound was found against Gram-positive bacteria, in particular against Bacillus subtilis ATCC 6633 and Staphylococcus aureus ATCC 6538 (MIC = $7.81 \mu \mathrm{g} / \mathrm{mL}$ ) and ATCC 43300 MRSA strains (MIC $=15.62 \mu \mathrm{g} / \mathrm{mL}$ ). Importantly, the best performing compounds did not show cytotoxicity against normal cell lines. It seems practical to use some of these compounds or their derivatives in the future in the prevention and treatment of infections caused by some pathogenic or opportunistic microorganisms.
\end{abstract}

Keywords: $N$-acetyl-1,3,4-oxadiazoline derivatives; antimicrobial activity; cytotoxicity; molecular modelling; acylhydrazones

\section{Introduction}

Antibiotic resistance describes the ability of bacteria to survive when exposed to antibiotics [1,2]. Once bacteria are exposed to antibiotics, there are three possibilities-the bacteria will die, stagnate (will not multiply) or will multiply. The third possibility is called antibiotic resistance, which poses a serious danger to public health worldwide. It leads to higher health care costs, longer hospitalization, patient failures and even deaths [3]. It turned out that it was necessary to introduce information and education activities in relation to medical professionals and to the entire society, as well as rigorous compliance with the rules of infection control and prevention of infections in all health care facilities (hospitals, outpatient facilities and nursing homes) [4]. Unfortunately, these actions are not sufficient and scientists are still constantly searching for new chemotherapeutic agents to help the immune system, while bacteria are constantly developing mechanisms that allow them to survive [5]. Bacterial strains resistant to all available antibiotics are already 
identified. Resistance to antibiotics is increasing faster than the pace of development of new pharmaceutics. Resistant microorganisms that pose a serious clinical and therapeutic problem include bacteria from Enterobacteriaceae family (Klebsiella pneumoniae and Escherichia coli) resistant to fluoroquinolones, third-generation cephalosporins, aminoglycosides and carbapenems, non-fermenting bacilli (Acinetobacter spp. and Pseudomonas), resistant to aminoglycosides and carbapenems, Enterococcus spp. resistant to vancomycin and linezolid and Streptococcus pneumoniae strain resistant to penicillin and the third-generation of cephalosporins. Staphylococcus aureus resistant to methicillin (MRSA), vancomycin (VISA) or linezolid is still a serious problem [6-11]. Particular attention is paid to golden staphylococcus (sometimes abbreviated as MRSA-methicillin-resistant Staphylococcus aureus) because it is a type of bacteria that more or less every third person transfers on the surface of the skin or in the nose, without becoming infected. However, S. aureus strain gets inside when skin is cut and can cause infection [12,13]. An antibiotic called methicillin is used to treat $S$. aureus infections. Staphylococcus aureus constitutes a variety of SA bacteria that are resistant to methicillin (and usually to some of the other antibiotics normally used to treat infections) [14-16]. Some microorganisms have acquired resistance to nearly all antibiotics. Therefore, the World Health Organization has published a list of antibiotic-resistant priority pathogens to which new antimicrobial agents are urgently needed. Some of them are listed in Table 1.

Table 1. Lists of common microorganisms with high antibiotic resistance.

\begin{tabular}{|c|c|c|c|}
\hline Microorganisms & Antibiotic Resistance & Type of Caused Infections/Diseases & References \\
\hline $\begin{array}{c}\text { Staphylococcus spp. (e.g., } \\
\text { Staphylococcus aureus, } \\
\text { Coagulase-negative staphylococci) }\end{array}$ & $\begin{array}{c}\text { methicillin (methicillin-resistant } S \text {. } \\
\text { aureus-MRSA and methicillin-resistant } \\
\text { coagulase-negative } \\
\text { staphylococci-MRCNS); vancomycin } \\
\text { (VISA-vancomycin-intermediate } \\
\text { S. aureus or } \\
\text { VRSA-vancomycin-resistant S. aureus) }\end{array}$ & $\begin{array}{l}\text { skin and soft-tissue infections (furuncles, } \\
\text { carbuncles), abscesses, osteomyelitis, } \\
\text { surgical site infections, bloodstream } \\
\text { infections, sepsis, pneumonia, } \\
\text { endocarditis, meningitis, urinary tract } \\
\text { infections, bone and joint infections, } \\
\text { osteoarticular infections, } \\
\text { infections associated with indwelling } \\
\text { devices, severe life-threatening systemic } \\
\text { infections }\end{array}$ & [17-26] \\
\hline $\begin{array}{c}\text { Enterococcus spp. } \\
\text { (e.g., E. faecalis, E. faecium) }\end{array}$ & $\begin{array}{c}\text { vancomycin } \\
\text { (VRE-vancomycin-resistant } \\
\text { enterococci) }\end{array}$ & $\begin{array}{l}\text { bloodstream infections, urinary tract } \\
\text { infections, surgical site infections, } \\
\text { meningitis, catheter-related infections }\end{array}$ & {$[17,22]$} \\
\hline Streptococcus spp. (e.g., S. pneumoniae) & $\begin{array}{c}\text { penicillin (PRP_-penicillin-resistant } \\
\text { S. pneumoniae) }\end{array}$ & $\begin{array}{l}\text { bloodstream infections, surgical site } \\
\text { infections, pneumonia, upper } \\
\text { respiratory tract infections, meningitis, } \\
\text { ear and sinus infections }\end{array}$ & {$[17,22]$} \\
\hline $\begin{array}{l}\text { Enterobacterales } \\
\text { (e.g., E. coli, } \\
\text { K. pneumoniae, } \\
\text { K. oxytoca, } \\
\text { Enterobacter spp.) }\end{array}$ & $\begin{array}{c}\text { beta-lactams (ESBL-extended spectrum } \\
\text { beta-lactamase producing } \\
\text { Enterobacterales), carbapenems } \\
\text { (CRE-carbapenem resistant } \\
\text { Enterobacterales) }\end{array}$ & $\begin{array}{l}\text { intra-abdominal infections and diseases } \\
\text { of abdomen, bloodstream infections, } \\
\text { urinary tract infections, surgical site } \\
\text { infections, pneumonia, upper } \\
\text { respiratory tract infections, meningeal, } \\
\text { eye, bone infections, skin and soft-tissue } \\
\text { infections, febrile neutropenia, surgical } \\
\text { wound infections }\end{array}$ & {$[17-19,22,27,28]$} \\
\hline $\begin{array}{l}\text { Non-fermenting Gram-negative rods } \\
\text { (e.g., Pseudomonas aeruginosa, } \\
\text { Acinetobacter spp.) }\end{array}$ & $\begin{array}{l}\text { carbapenems (multi-drug resistant } \\
\text { P. aeruginosa, carbapenem resistant } \\
\text { Acinetobacter) }\end{array}$ & $\begin{array}{l}\text { pneumonia, bloodstream infections, skin } \\
\text { and soft-tissue infection (burns), } \\
\text { complicated urinary tract infections and } \\
\text { abdominal infections, heart, brain, } \\
\text { catheter-related, and at surgical sites }\end{array}$ & {$[17,19,22,28]$} \\
\hline $\begin{array}{c}\text { Candida spp. } \\
\text { (e.g., C. auris, C. glabrata) }\end{array}$ & azoles & $\begin{array}{l}\text { bloodstream infections, urinary tract } \\
\text { infections, pneumonia, superficial and } \\
\text { mucosal infections, life-threatening } \\
\text { disseminated candidiasis }\end{array}$ & {$[17,19,22,29,30]$} \\
\hline
\end{tabular}

Candida albicans is one of the species of microorganisms that belong to the natural physiological flora of the human body. This fungus is isolated from the mucous membranes of the digestive tract, respiratory tract, mouth and skin. Unfortunately, these species can also cause opportunistic infections. First of all, these are non-dangerous, but troublesome to heal, surface yeasts [31]. Systemic candidiasis appears more and more often and constitutes a bigger problem. They are observed in patients with severe immunodeficiency, caused by long-term therapy or diseases which cause a decrease of the immune response, such 
as cancer or AIDS [32]. Unfortunately, in recent years, an increase in the number of isolated strains resistant to the antifungal agents used so far has been additionally observed. Moreover, some of them show resistance to many pharmaceutics at once, this is called multidrug resistance (MDR). This makes the candidiasis treatments ineffective [33].

Invasive Candida infections remain an important cause of morbidity and mortality, especially in hospitalized and immunocompromised or critically ill patients. Currently, there are only three major classes of medicines approved for the treatment of serious candidiasis. Moreover, the efficacy of these antimycotics is also compromised by the development of drug resistance in this pathogen population $[29,30]$.

That is why it is so important to search for new molecules that will be able to fight even with the most resistant strains of bacteria or fungi and at the same time will be safe for the human body.

An important group of compounds that can constitute a good starting point for the development of new antibacterial and antifungal agents are acylhydrazones as well as 1,3,4-oxadiazole derivatives. Acylhydrazones have a wide spectrum of biological activity, including: antibacterial [34-36], antifungal [37], antitubercular [38] and anticancer properties [39,40]. Similarly, the derivatives of 1,3,4-oxadiazole have documented antibacterial [41-44], antifungal [45,46], anticancer [47,48] and antimycobacterial [49,50] action. Therefore, our research goal was based on the synthesis of appropriate acylhydrazones which subsequently were transformed into 3-acetyl-2,5-disubstituted-1,3,4-oxadiazole derivatives. The starting compound for our syntheses was nicotinic acid hydrazide. Nicotinic acid is known collectively as vitamin B3 or vitamin PP. It has no proven antibacterial effect, but vitamin B3 increases the ability of immune cells to fight against Staphylococcus aureus bacteria because it increases the number of white blood cells (neutrophils), which possess a bactericidal effect [51].

Having in mind these facts, in this research we decided to design, synthetize, evaluate for antimicrobial activity and cytotoxicity and perform molecular docking studies of acylhydrazones and 1,3,4-oxadiazole derivatives obtained from nicotinic acid hydrazide.

\section{Results}

\subsection{Chemistry}

In this paper, we present the synthesis of a series of new acylhydrazones (2-13) and 3acetyl-2,5-disubstituted-1,3,4-oxadiazoline derivatives (14-25) (Scheme 1). Novel molecules were obtained with a $63-96 \%$ yield. The 1,3,4-oxadiazoline derivatives were obtained with a lower yield. The presented synthesis was carried out in two stages. Initially, a series of new acylhydrazones (2-13) was obtained as a result of the condensation reaction of nicotinic acid hydrazide (1) with the appropriate aldehydes. Then, the obtained compounds (2-13) were subjected to the cyclization reaction in acetic anhydride in order to synthesize novel 1,3,4-oxadiazoline derivatives. All synthesized compounds are solids and can be dissolved in DMSO at room temperature.

The structure of all obtained compounds was confirmed by spectroscopic methods: ${ }^{1} \mathrm{H}$ NMR, ${ }^{13} \mathrm{C}$ NMR and FT-IR spectra as well as elemental analysis.

The first group of compounds, i.e., acylhydrazones (2-13), showed the following characteristic signals in the ${ }^{1} \mathrm{H}$ NMR spectra: singlet for the $\mathrm{NH}$ group in the range of $11.73-12.91 \mathrm{ppm}$ and the signal for the $=\mathrm{CH}$ group at $\delta 8.23-9.11 \mathrm{ppm}$. In the case of the ${ }^{13} \mathrm{C}$ NMR spectra, the signals for the carbon atom of $=\mathrm{CH}$ and $\mathrm{C}=\mathrm{O}$ groups appeared in the range of $\delta 137.11-138.61 \mathrm{ppm}$ and 161.18-185.41 ppm, respectively. Additionally, we observed characteristic signals in expected regions in the FT-IR spectra. The remaining fragments of the examined compounds gave characteristic signals in the expected ranges of the chemical shift. 


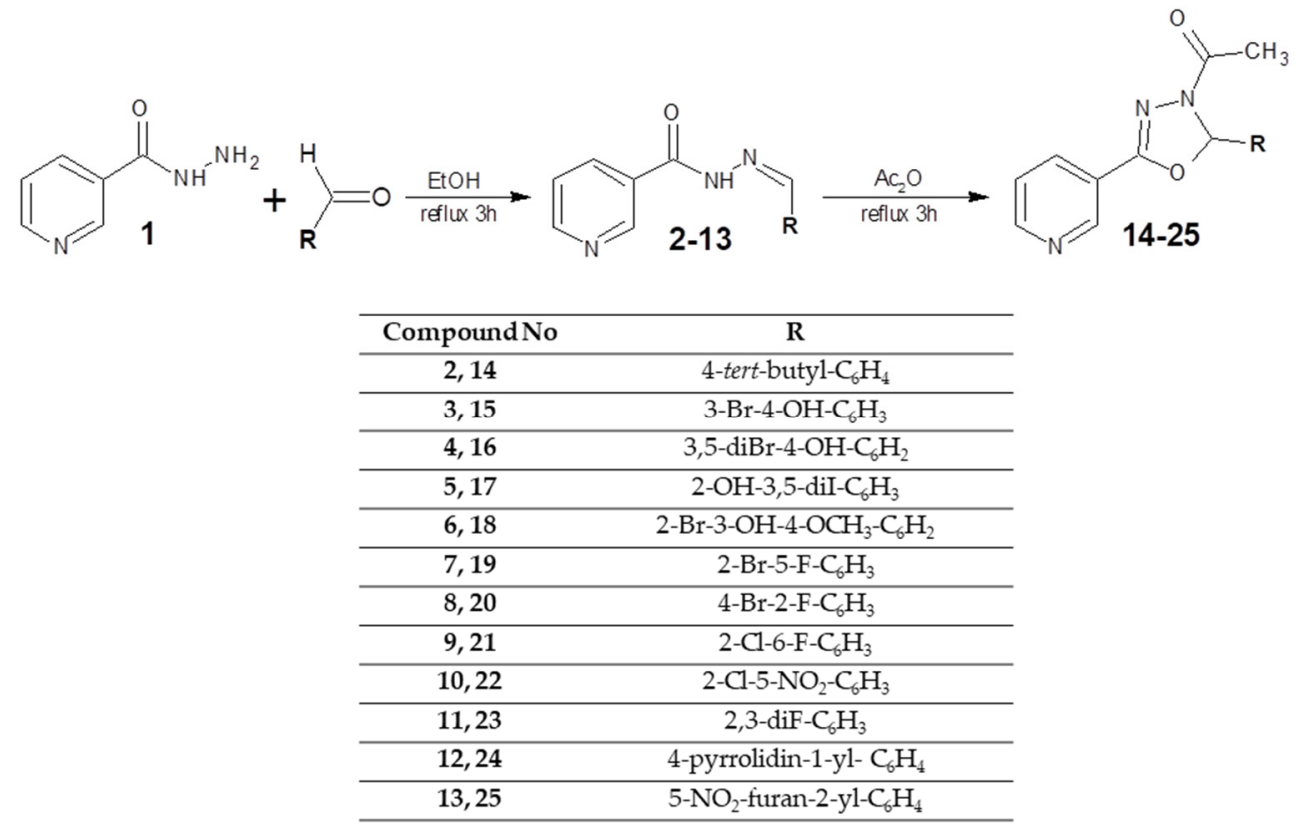

Scheme 1. Reaction leading to novel 3-acetyl-2,5-disubstituted-1,3,4-oxadiazoline derivatives.

The 3-acetyl-2,5-disubstituted-1,3,4-oxadiazoline derivatives (14-25) in the ${ }^{1} \mathrm{H} \mathrm{NMR}$, showed a singlet signal for the proton of $\mathrm{CH}$ group of the 1,3,4-oxadiazoline system at $\delta$ 7.15-10.01 ppm and for the protons of the acetyl substituent in the range of $\delta 1.93-2.57 \mathrm{ppm}$. Signals for the carbon atom of the $\mathrm{CH}$ group of 1,3,4-oxadiazoline system and for the carbon atom of 1,3,4-oxadiazoline ring in the ${ }^{13} \mathrm{C}$ NMR spectra were found at $\delta 88.41-125.08 \mathrm{ppm}$ and $\delta$ 150.83-155.08 ppm, respectively. Similarly, the signal for the carbon atom of the methyl group of the acetyl substituent appeared around $20 \mathrm{ppm}$. Additionally, we observed characteristic signals for $\mathrm{C}=\mathrm{O}, \mathrm{C}=\mathrm{N}$ and $\mathrm{C}-\mathrm{OC}$ bonds at the expected values in FT-IR spectra.

\subsection{Microbiology}

All synthesized compounds (2-25) were examined for their antimicrobial activity against Gram-positive bacteria, Gram-negative bacteria and fungi belonging to yeasts Candida spp. A panel of reference strains of microorganisms also included some resistant staphylococci, that is the methicillin-resistant Staphylococcus aureus MRSA ATCC 43300. On the basis of MIC and MBC values, we discovered that new compounds showed interesting antibacterial activity. Table 2 presents the compounds which displayed antimicrobial activity.

The obtained results showed a very high antibacterial effect of compounds $\mathbf{5}$ and $\mathbf{1 3}$ against Gram-positive bacteria (Table 2). Their activity was strong or very strong with minimal inhibitory concentrations (MIC) ranging from $7.81 \mu \mathrm{g} / \mathrm{mL}$ to $15.62 \mu \mathrm{g} / \mathrm{mL}$ and from $1.95 \mu \mathrm{g} / \mathrm{mL}$ to $15.62 \mu \mathrm{g} / \mathrm{mL}$, respectively. In turn, ranges of minimal bactericidal concentrations (MBC) values were $7.81-31.25 \mu \mathrm{g} / \mathrm{mL}$ for 5 and $3.91-31.25 \mu \mathrm{g} / \mathrm{mL}$ for compound 13. Moreover, these substances showed a bactericidal effect (MBC/MIC $=1-4)$.

Additionally, two of the tested compounds showed activity against the MRSA strain Staphylococcus aureus ATCC 43300 (compound 5: MIC = $15.62 \mu \mathrm{g} / \mathrm{mL}$, compound 13: $\mathrm{MIC}=7.81 \mu \mathrm{g} / \mathrm{mL})$.

Gram-negative bacteria were less sensitive to these compounds. Acylhydrazone numbered as $\mathbf{1 3}$ had good or moderate bactericidal activity against all rod-shaped bacteria with $\mathrm{MIC}=31.25-500 \mu \mathrm{g} / \mathrm{mL}$ and $\mathrm{MBC}=31.25-1000 \mu \mathrm{g} / \mathrm{mL}(\mathrm{MBC} / \mathrm{MIC}=1-4)$. In turn, compound 5 indicated activity towards Bordetella bronchiseptica ATCC 4617 (MIC $=62.5 \mu \mathrm{g} / \mathrm{mL}$, $\mathrm{MBC}=125 \mu \mathrm{g} / \mathrm{mL}$ and $\mathrm{MBC} / \mathrm{MIC}=2)$. The remaining bacteria were insensitive to these compounds. Other newly synthesized compounds showed some activity against staphylococci or micrococci (only compounds 7 and 9) or were inactive towards reference bacteria. 
Table 2. The activity data of acylhydrazones and 3-acetyl-1,3,4-oxadiazoline derivatives expressed as MIC (MBC or MFC) $(\mu \mathrm{g} / \mathrm{mL})$ and $\{\mathrm{MBC} / \mathrm{MIC}$ or MFC $/ \mathrm{MIC}\}$ values against the reference strains of microorganisms.

\begin{tabular}{|c|c|c|c|c|c|c|c|c|c|c|c|c|c|c|c|c|c|}
\hline & \multirow[b]{2}{*}{$\begin{array}{l}\text { Species/ } \\
\text { Compound }\end{array}$} & \multicolumn{16}{|c|}{ MIC (MBC or MFC) ( $\mu \mathrm{g} / \mathrm{mL})$ and $\{\mathrm{MBC} / \mathrm{MIC}$ or MFC/MIC\} of Compounds and Reference Substances } \\
\hline & & 5 & 7 & 9 & 13 & 14 & 15 & 16 & 17 & 18 & 23 & 24 & 25 & $\begin{array}{l}\mathrm{CIP} / \\
\mathrm{VA}^{* /} \\
\mathrm{NY}^{* *}\end{array}$ & NIT & CFX & APC \\
\hline \multirow{8}{*}{ 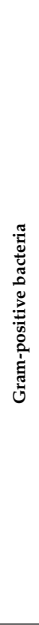 } & $\begin{array}{c}\text { Staphylococcus } \\
\text { aureus } \\
\text { ATCC } 6538\end{array}$ & $\begin{array}{c}7.81 \\
(15.62) \\
\{2\}\end{array}$ & - & $\begin{array}{c}500 \\
(>1000) \\
\{>2\}\end{array}$ & $\begin{array}{c}3.91 \\
(3.91) \\
\{\mathbf{1}\}\end{array}$ & $\begin{array}{c}1000 \\
(1000) \\
\{\mathbf{1}\}\end{array}$ & $\begin{array}{c}125 \\
(>1000) \\
\{>8\}\end{array}$ & $\begin{array}{c}1000 \\
(>1000) \\
\{>1\}\end{array}$ & $\begin{array}{c}15.62 \\
(62.5) \\
\{4\}\end{array}$ & - & - & $\begin{array}{l}500 \\
(500) \\
\{\mathbf{1}\}\end{array}$ & $\begin{array}{c}7.81 \\
(7.81) \\
\{\mathbf{1}\}\end{array}$ & $\begin{array}{c}0.24 \\
(0.24) \\
\{1\}\end{array}$ & $\begin{array}{c}15.62 \\
(15.62)\end{array}$ & 0.98 & nd \\
\hline & $\begin{array}{c}\text { Staphylococcus } \\
\text { aureus } \\
\text { ATCC } 43300\end{array}$ & $\begin{array}{c}15.62 \\
(31.25) \\
\{2\} \\
\end{array}$ & - & - & $\begin{array}{c}7.81 \\
(31.25) \\
\{4\}\end{array}$ & - & $\begin{array}{c}250 \\
(>1000) \\
\{>4\}\end{array}$ & - & $\begin{array}{c}31.25 \\
(31.25) \\
\{\mathbf{1}\} \\
\end{array}$ & - & - & - & $\begin{array}{c}15.62 \\
(31.25) \\
\{2\}\end{array}$ & $\begin{array}{c}0.24 \\
(0.24) \\
\{1\} \\
\end{array}$ & $\begin{array}{c}7.81 \\
(15.62)\end{array}$ & nd & nd \\
\hline & $\begin{array}{l}\text { Staphylococcus } \\
\text { aureus } \\
\text { ATCC } 29213\end{array}$ & $\begin{array}{c}7.81 \\
(15.62) \\
\{2\}\end{array}$ & $\cdot$ & - & $\begin{array}{c}7.81 \\
(7.81) \\
\{1\}\end{array}$ & $\cdot$ & $\begin{array}{c}1000 \\
(>1000) \\
\{>1\}\end{array}$ & $\begin{array}{c}1000 \\
(>1000) \\
\{>1\}\end{array}$ & $\begin{array}{c}31.25 \\
(125) \\
\{4\}\end{array}$ & - & - & - & $\begin{array}{c}15.62 \\
(15.62) \\
\{\mathbf{1}\}\end{array}$ & $\begin{array}{c}0.48 \\
(0.48) \\
\{\mathbf{1}\}\end{array}$ & nd & nd & nd \\
\hline & $\begin{array}{c}\text { Staphylococcus } \\
\text { epidermidis } \\
\text { ATCC } 12228\end{array}$ & $\begin{array}{c}7.81 \\
(7.81) \\
\{\mathbf{1}\} \\
\end{array}$ & - & $\begin{array}{c}62.5 \\
(500) \\
\{8\} \\
\end{array}$ & $\begin{array}{c}1.95 \\
(3.91) \\
\{2\} \\
\end{array}$ & - & $\begin{array}{c}500 \\
(1000) \\
\{2\} \\
\end{array}$ & - & $\begin{array}{c}7.81 \\
(7.81) \\
\{\mathbf{1}\} \\
\end{array}$ & - & - & - & $\begin{array}{c}15.62 \\
(15.62) \\
\{\mathbf{1}\}\end{array}$ & $\begin{array}{c}0.12 \\
(0.12) \\
\{\mathbf{1}\} \\
\end{array}$ & $\begin{array}{c}3.91 \\
(7.81)\end{array}$ & 0.24 & nd \\
\hline & $\begin{array}{c}\text { Enterococcus } \\
\text { faecalis } \\
\text { ATCC } 29212\end{array}$ & $\begin{array}{c}7.81 \\
(31.25) \\
\{4\} \\
\end{array}$ & - & - & $\begin{array}{c}15.62 \\
(31.25) \\
\{2\}\end{array}$ & - & - & - & $\begin{array}{c}31.25 \\
(125) \\
\{4\}\end{array}$ & - & - & - & $\begin{array}{c}62.5 \\
(125) \\
\{2\} \\
\end{array}$ & $\begin{array}{c}0.98^{*} \\
(1.95) \\
\{2\}\end{array}$ & nd & nd & nd \\
\hline & $\begin{array}{l}\text { Micrococcus } \\
\text { luteus } \\
\text { ATCC } 10240\end{array}$ & $\begin{array}{c}7.81 \\
(15.62) \\
\{2\} \\
\end{array}$ & $\begin{array}{c}1000 \\
(>1000) \\
\{>\mathbf{1}\}\end{array}$ & $\begin{array}{c}1000 \\
(>1000) \\
\{>1\}\end{array}$ & $\begin{array}{c}15.62 \\
(15.62) \\
\{1\}\end{array}$ & $\begin{array}{c}500 \\
(1000) \\
\{2\}\end{array}$ & $\begin{array}{c}1000 \\
(1000) \\
\{\mathbf{1}\}\end{array}$ & $\begin{array}{c}500 \\
(1000) \\
\{2\}\end{array}$ & $\begin{array}{c}31.25 \\
(125) \\
\{4\} \\
\end{array}$ & - & $\begin{array}{l}500 \\
(>1000) \\
\{>2\}\end{array}$ & $\begin{array}{c}250 \\
(500) \\
\{2\} \\
\end{array}$ & $\begin{array}{c}15.62 \\
(31.25) \\
\{2\}\end{array}$ & $\begin{array}{c}0.98 \\
(1.95) \\
\{2\} \\
\end{array}$ & $\begin{array}{l}62.5 \\
(62.5)\end{array}$ & 0.98 & nd \\
\hline & $\begin{array}{c}\text { Bacillus } \\
\text { subtilis } \\
\text { ATCC } 6633\end{array}$ & $\begin{array}{c}15.62 \\
(15.62) \\
\{\mathbf{1}\} \\
\end{array}$ & - & - & $\begin{array}{c}7.81 \\
(7.81) \\
\{1\}\end{array}$ & - & $\begin{array}{c}1000 \\
(>1000) \\
\{>1\}\end{array}$ & - & $\begin{array}{c}62.5 \\
(125) \\
\{2\}\end{array}$ & - & - & $\begin{array}{c}1000 \\
(>1000) \\
\{>1\}\end{array}$ & $\begin{array}{c}7.81 \\
(7.81) \\
\{\mathbf{1}\} \\
\end{array}$ & $\begin{array}{c}0.03 \\
(0.03) \\
\{\mathbf{1}\} \\
\end{array}$ & $\begin{array}{c}3.91 \\
(3.91)\end{array}$ & 15.62 & 62.5 \\
\hline & $\begin{array}{c}\text { Bacillus } \\
\text { cereus } \\
\text { ATCC } 10876\end{array}$ & $\begin{array}{c}7.81 \\
(31.25) \\
\{4\}\end{array}$ & - & - & $\begin{array}{c}15.62 \\
(31.25) \\
\{2\}\end{array}$ & - & $\begin{array}{c}500 \\
(>1000) \\
\{>2\}\end{array}$ & - & $\begin{array}{c}31.25 \\
(62.5) \\
\{2\}\end{array}$ & - & - & - & $\begin{array}{c}31.25 \\
(62.5) \\
\{2\}\end{array}$ & $\begin{array}{c}0.06 \\
(0.12) \\
\{2\}\end{array}$ & $\begin{array}{c}7.81 \\
(15.62)\end{array}$ & 31.25 & nd \\
\hline \multirow{6}{*}{ 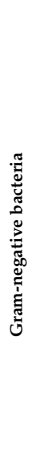 } & $\begin{array}{c}\text { Bordetella } \\
\text { bronchiseptica } \\
\text { ATCC } 4617\end{array}$ & $\begin{array}{c}62.5 \\
(125) \\
\{2\}\end{array}$ & - & - & $\begin{array}{c}500 \\
(1000) \\
\{2\}\end{array}$ & - & - & - & - & - & - & - & $\begin{array}{l}125 \\
(125) \\
\{\mathbf{1}\}\end{array}$ & $\begin{array}{l}0.98 \\
(0.98) \\
\{\mathbf{1}\}\end{array}$ & $\begin{array}{c}125 \\
(>1000)\end{array}$ & nd & nd \\
\hline & $\begin{array}{c}\text { Klebsiella } \\
\text { pneumoniae } \\
\text { ATCC } 13883\end{array}$ & - & - & - & $\begin{array}{c}250 \\
(1000) \\
\{4\}\end{array}$ & - & - & - & - & - & - & - & $\begin{array}{l}125 \\
(125) \\
\{\mathbf{1}\}\end{array}$ & $\begin{array}{c}0.12 \\
(0.24) \\
\{2\}\end{array}$ & $\begin{array}{r}15.62 \\
(31.25)\end{array}$ & nd & nd \\
\hline & $\begin{array}{c}\text { Proteus } \\
\text { mirabilis } \\
\text { ATCC } 12453\end{array}$ & - & - & - & $\begin{array}{c}62.5 \\
(125) \\
\{2\}\end{array}$ & - & - & - & - & - & - & - & $\begin{array}{c}62.5 \\
(125) \\
\{2\}\end{array}$ & $\begin{array}{c}0.03 \\
(0.03) \\
\{\mathbf{1})\end{array}$ & $\begin{array}{l}62.5 \\
(125)\end{array}$ & nd & nd \\
\hline & $\begin{array}{c}\text { Salmonella } \\
\text { typhimurium } \\
\text { ATCC } 14028\end{array}$ & - & - & - & $\begin{array}{c}31.25 \\
(31.25) \\
\{\mathbf{1}\}\end{array}$ & - & - & - & - & - & - & - & $\begin{array}{c}62.5 \\
(125) \\
\{2\}\end{array}$ & $\begin{array}{c}0.06 \\
(0.06) \\
\{\mathbf{1}\}\end{array}$ & $\begin{array}{l}31.25 \\
(62.5)\end{array}$ & nd & nd \\
\hline & $\begin{array}{c}\text { Escherichia } \\
\text { coli } \\
\text { ATCC } 25922\end{array}$ & - & - & - & $\begin{array}{c}31.25 \\
(31.25) \\
\{\mathbf{1}\}\end{array}$ & - & - & - & - & - & - & - & $\begin{array}{c}31.25 \\
(62.5) \\
\{2\}\end{array}$ & $\begin{array}{c}0.004 \\
(0.008) \\
\{2\}\end{array}$ & $\begin{array}{c}7.81 \\
(15.62)\end{array}$ & nd & nd \\
\hline & $\begin{array}{l}\text { Pseudomonas } \\
\text { aeruginosa } \\
\text { ATCC } 9027\end{array}$ & - & - & - & $\begin{array}{l}250 \\
(500) \\
\{2\}\end{array}$ & - & - & - & - & - & - & - & $\begin{array}{l}250 \\
(250) \\
\{\mathbf{1}\}\end{array}$ & $\begin{array}{c}0.48 \\
(0.98) \\
\{2\}\end{array}$ & nd & nd & nd \\
\hline \multirow{5}{*}{ 总 } & $\begin{array}{c}\text { Candida } \\
\text { albicans } \\
\text { ATCC } 2091\end{array}$ & $\begin{array}{c}250 \\
(1000) \\
\{4\}\end{array}$ & - & - & - & $\begin{array}{c}1000 \\
(>1000) \\
\{>1\}\end{array}$ & $\begin{array}{c}1000 \\
(>1000) \\
\{>1\}\end{array}$ & - & - & $\begin{array}{l}1000 \\
(>1000) \\
\{>1\}\end{array}$ & $\begin{array}{l}1000 \\
(1000) \\
\{1\}\end{array}$ & $\begin{array}{c}500 \\
(500) \\
\{1\}\end{array}$ & $\begin{array}{c}125 \\
(125) \\
\{\mathbf{1}\}\end{array}$ & $\begin{array}{c}0.24 * * \\
(0.24) \\
\{1\}\end{array}$ & na & na & na \\
\hline & $\begin{array}{c}\text { Candida } \\
\text { albicans } \\
\text { ATCC } 10231\end{array}$ & $\begin{array}{c}125 \\
(1000) \\
\{8\}\end{array}$ & - & - & - & $\begin{array}{c}1000 \\
(>1000) \\
\{>1\}\end{array}$ & $\begin{array}{c}1000 \\
(>1000) \\
\{>1\}\end{array}$ & - & - & $\begin{array}{l}1000 \\
(>1000) \\
\{>1\}\end{array}$ & $\begin{array}{l}500 \\
(>1000) \\
\{>2\}\end{array}$ & $\begin{array}{c}500 \\
(1000) \\
\{2\}\end{array}$ & $\begin{array}{c}15.62 \\
(31.25) \\
\{2\}\end{array}$ & $\begin{array}{c}0.48^{* *} \\
(0.48) \\
\{1\}\end{array}$ & na & na & na \\
\hline & $\begin{array}{c}\text { Candida } \\
\text { parapsilosis } \\
\text { ATCC } 22019\end{array}$ & $\begin{array}{c}250 \\
(1000) \\
\{4\}\end{array}$ & - & - & - & $\begin{array}{c}1000 \\
(>1000) \\
\{>1\}\end{array}$ & $\begin{array}{c}1000 \\
(>1000) \\
\{>1\}\end{array}$ & - & - & $\begin{array}{l}500 \\
(>1000) \\
\{>2\}\end{array}$ & $\begin{array}{l}1000 \\
(>1000) \\
\{>1\}\end{array}$ & $\begin{array}{c}500 \\
(1000) \\
\{2\}\end{array}$ & $\begin{array}{c}15.62 \\
(31.25) \\
\{2\}\end{array}$ & $\begin{array}{c}0.24^{* *} \\
(0.48) \\
\{2\}\end{array}$ & na & na & na \\
\hline & $\begin{array}{c}\text { Candida } \\
\text { glabrata } \\
\text { ATCC } 90030\end{array}$ & $\begin{array}{c}62.5 \\
(500) \\
\{8\}\end{array}$ & - & - & - & $\begin{array}{c}1000 \\
(>1000) \\
\{>1\}\end{array}$ & - & - & - & - & $\begin{array}{l}1000 \\
(>1000) \\
\{>1\}\end{array}$ & $\begin{array}{c}500 \\
(1000) \\
\{2\}\end{array}$ & $\begin{array}{l}500 \\
(500) \\
\{\mathbf{1}\}\end{array}$ & $\begin{array}{c}0.24 * * \\
(0.48) \\
\{2\}\end{array}$ & na & na & na \\
\hline & $\begin{array}{c}\text { Candida } \\
\text { krusei } \\
\text { ATCC } 14243\end{array}$ & $\begin{array}{c}250 \\
(1000) \\
\{4\}\end{array}$ & - & - & - & $\begin{array}{c}1000 \\
(>1000) \\
\{>1\}\end{array}$ & $\begin{array}{c}1000 \\
(>1000) \\
\{>1\}\end{array}$ & - & - & - & - & $\begin{array}{l}500 \\
(500) \\
\{\mathbf{1}\}\end{array}$ & $\begin{array}{l}250 \\
(250) \\
\{\mathbf{1}\}\end{array}$ & $\begin{array}{c}0.24 * * \\
(0.24) \\
\{1\}\end{array}$ & na & na & na \\
\hline
\end{tabular}

'-': no activity; nd: not determined; na: not applicable. The standard chemotherapeutics used as positive controls: ciprofloxacin (CIP), nitrofurantoin (NIT), cefuroxime (CFX) and ampicillin (APC) for bacteria except Enterococcus faecalis ATCC 29212, vancomycin (VA*) for Enterococcus faecalis ATCC 29212 and nystatin (NY**) for fungi. Compounds with bactericidal effect $(\mathrm{MBC} / \mathrm{MIC} \leq 4)$ or fungicidal effect $(\mathrm{MFC} / \mathrm{MIC} \leq 4)$ are marked with bold font; No bioactivity-MIC $>1000 \mu \mathrm{g} / \mathrm{mL}$; mild bioactivity-MIC $=501-1000 \mu \mathrm{g} / \mathrm{mL}$; moderate bioactivity$\mathrm{MIC}=126-500 \mu \mathrm{g} / \mathrm{mL}$; good bioactivity-MIC $=26-125 \mu \mathrm{g} / \mathrm{mL}$; strong bioactivity-MIC $=10-25 \mu \mathrm{g} / \mathrm{mL}$; very strong bioactivity-MIC $<10 \mu \mathrm{g} / \mathrm{mL} ; *$ : vancomycin activity; **: nystatin activity.

The yeasts, belonging to reference Candida spp. were sensitive only to compound 5 . Antifungal activity of 5 was good or moderate $(\mathrm{MIC}=62.5-250 \mu \mathrm{g} / \mathrm{mL}$ and $\mathrm{MFC}=500-1000 \mu \mathrm{g} / \mathrm{mL}$ ) with fungicidal $(\mathrm{MFC} / \mathrm{MIC}=4)$ or fungistatic $(\mathrm{MFC} / \mathrm{MIC}=8)$ effect. 
In the case of the 3-acetyl-2,5-disubstituted-1,3,4-oxadiazoline derivatives, the widest spectrum of activity, with bactericidal and fungicidal effect (MBC $/ \mathrm{MIC}=\mathrm{MFC} / \mathrm{MIC}=1-2)$, was shown by derivative 25 towards all reference bacteria and yeasts (Table 2). Gram-positive bacteria were the most sensitive $(\mathrm{MIC}=7.81-62.5 \mu \mathrm{g} / \mathrm{mL}$ and $\mathrm{MBC}=7.81-125 \mu \mathrm{g} / \mathrm{mL}$ ). Compounds numbered as 15, 17, 25 were active against the MRSA strain Staphylococcus aureus ATCC 43300. Their activity was strong to moderate (MIC $=15.62-250 \mu \mathrm{g} / \mathrm{mL}$ ). Compound $25 \mathrm{in}-$ dicated good effect towards Gram-negative microorganisms with $\mathrm{MIC}=31.25-125 \mu \mathrm{g} / \mathrm{mL}$ and $\mathrm{MBC}=62.5-125 \mu \mathrm{g} / \mathrm{mL}$ towards all strains except Pseudomonas aeruginosa ATCC 9027 (moderate activity; $\mathrm{MIC}=\mathrm{MBC}=250 \mu \mathrm{g} / \mathrm{mL}$ ). Gram-negative bacteria were sensitive only to this compound.

Moreover, the 1,3,4-oxadiazoline derivative 17 had bactericidal effect (MBC/MIC = 1-4) with very strong or strong activity $(\mathrm{MIC}=7.81-15.62 \mu \mathrm{g} / \mathrm{mL}, \mathrm{MBC}=7.81-62.5 \mu \mathrm{g} / \mathrm{mL}$ ) against Staphylococcus epidermidis ATCC 12228 or Staphylococcus aureus ATCC 6538 and good activity towards other Gram-positive bacteria $(\mathrm{MIC}=31.25-62.5 \mu \mathrm{g} / \mathrm{mL}, \mathrm{MBC}=31.25-125 \mu \mathrm{g} / \mathrm{mL}$ ). The remaining newly synthesized compounds $(14,15,16,23$ and 24) were less active against cocci and bacilli or were inactive towards reference strains of bacteria.

Compound 25 also indicated a high fungicidal effect towards Candida spp. with MIC values ranging from $15.62 \mu \mathrm{g} / \mathrm{mL}$ to $500 \mu \mathrm{g} / \mathrm{mL}$ and MFC from $31.25 \mu \mathrm{g} / \mathrm{mL}$ to $500 \mu \mathrm{g} / \mathrm{mL}$ ). Yeasts belonging to C. albicans ATCC 10231 and C. parapsilosis ATCC 22019 were especially sensitive to this substance (MIC $=15.62 \mu \mathrm{g} / \mathrm{mL}$ and two-fold higher MFC value). The molecule 24 was slightly less active (moderate activity; MIC $=500 \mu \mathrm{g} / \mathrm{mL}$ and MFC $=500-1000 \mu \mathrm{g} / \mathrm{mL}$ ). The antifungal effect of some other substances was moderate or mild $(14,15,18$ and 23). The remaining compounds were inactive towards fungi.

\subsection{Cytotoxicity Studies}

The analysis of cells' sensitivity to the tested compounds was performed with the use of the MTT method-analysis of the metabolic activity of cells and NR uptake assay analysing the stability of cell membranes and thus direct cytotoxicity.

The MTT method showed a higher sensitivity of colon epithelial tumour cells to the analysed compounds than normal cells of the colonic epithelium. Compound 21 had the weakest effect on tumour cells, reducing their metabolic activity to $80 \%$ at the compound concentration of $200 \mu \mathrm{g} / \mathrm{mL}$. The strongest activity was shown by compound 17, which reduced the metabolic activity of cells to $41 \%$ at the concentration of $75 \mu \mathrm{g} / \mathrm{mL}$ in comparison to the control (100\% activity), not treated with the tested substances. The $\mathrm{IC}_{50}$ value, in this case, was $61.18 \mu \mathrm{g} / \mathrm{mL}$. In the case of normal cells, the highest decrease in cell metabolic activity was also demonstrated after compound $\mathbf{1 7}$ application. However, at the concentration of $200 \mu \mathrm{g} / \mathrm{mL}$, cell metabolism decreased only to $71.6 \%$ as compared with the untreated control (Figure 1).

Carrying out the analysis by the neutral red uptake (NR), there were slight differences in the sensitivity of the cells to the tested compounds in comparison to the results obtained with the MTT method. In the case of tumour cells, all tested compounds showed similar cytotoxic activity. At the highest concentration of the compounds ( $200 \mu \mathrm{g} / \mathrm{mL})$, HT29 cell viability oscillated between $70 \%$ and $78 \%$. In the case of normal colonic epithelial cells, the compound numbered $\mathbf{2 0}$ maintained cell viability over the control value at the entire range of tested concentrations. Compounds 21 and 22 at the concentration of $200 \mu \mathrm{g} / \mathrm{mL}$ decreased cell viability to 85 and $80 \%$, respectively. Compound 17 showed the strongest cytotoxic activity against these cells, reducing their viability to $46 \%$ at the highest applied concentration $(200 \mu \mathrm{g} / \mathrm{mL})$. This allowed the calculation of an $\mathrm{IC}_{50}$ value for this compound against normal cells at $179.81 \mu \mathrm{g} / \mathrm{mL}$ (Figure 2). 


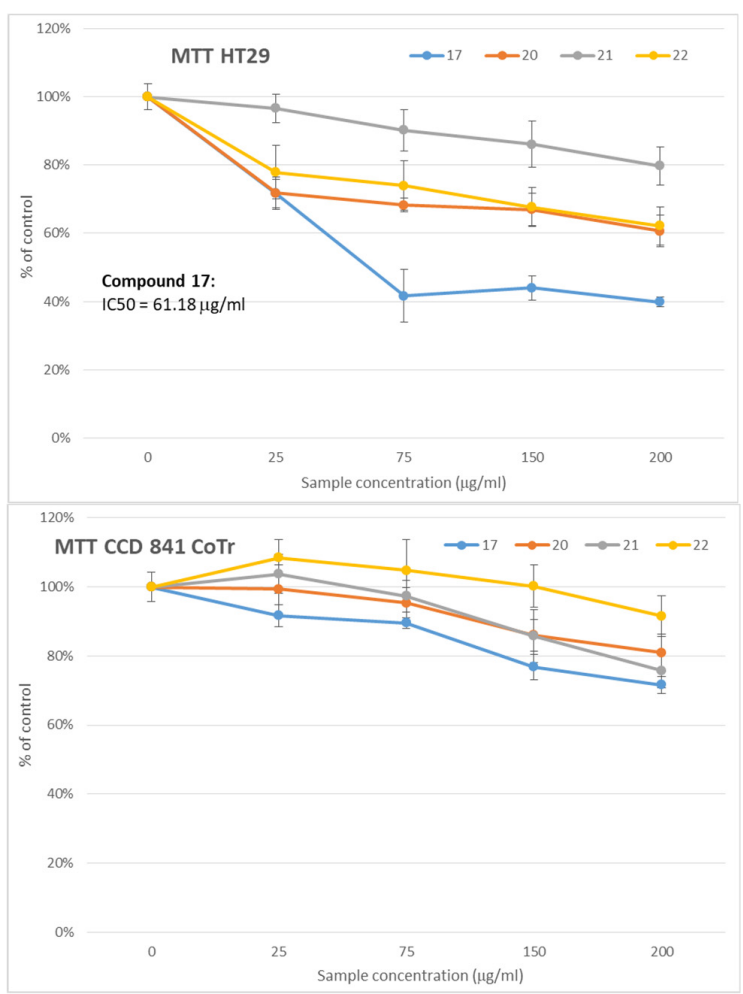

Figure 1. MTT assay results for compounds 17, 20, 21 and 22. MTT HT29: human colon adenocarcinoma cell line (ATCC No. HTB-38) MTT test results; MTT CCD 841 CoTr: human normal colon epithelial cells (ATCC No. CRL-1807) MTT test results.

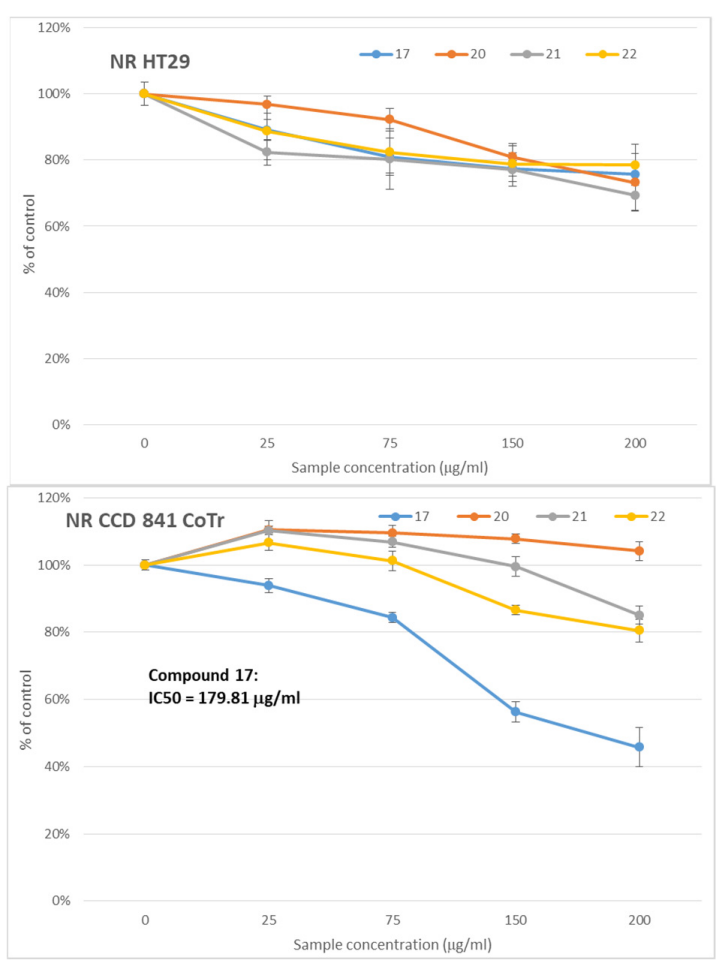

Figure 2. Graphs showing activity of compounds 17, 20, 21 and 22 during the neutral red uptake NR assay. NR HT29: human colon adenocarcinoma cell line (ATCC No. HTB-38) neutral red uptake NR assay results; NR CCD 841 CoTr: human normal colon epithelial cells (ATCC No. CRL-1807) neutral red uptake NR assay results. 
The tested compounds $(\mathbf{1 7}, \mathbf{2 0}, \mathbf{2 1}, \mathbf{2 2})$ stimulated the production of nitric oxide (NOx) by both normal and tumour cells derived from the human colonic epithelium. However, a different reaction of both types of cells to increasing concentrations of the tested compounds can be observed. In the case of analyses performed on cancer cells, the lowest concentrations of the tested compounds $(25 \mu \mathrm{g} / \mathrm{mL})$, significantly stimulated the production and release of nitric oxide to values exceeding $0.5 \mu \mathrm{M}$ as compared to the control $(0.147 \mu \mathrm{M})$. The increasing concentrations of the tested compounds $(\mathbf{1 7}, \mathbf{2 0}, \mathbf{2 1}, \mathbf{2 2})$ were less effective in inducing the release and production of nitric oxide. The highest concentration $(200 \mu \mathrm{g} / \mathrm{mL})$ of the compounds led to the production of nitric oxide by tumour cells at the level of $0.372 \mu \mathrm{M}(\mathbf{1 7})$ to $0.101 \mu \mathrm{M}$ (22). Analysing normal cells, it was shown that the tested substances stimulated the release of nitric oxide with increasing concentration of the compound. Substance $\mathbf{1 7}$ had the strongest stimulating effect on the production of NOx by normal cells. At the highest concentration $(200 \mu \mathrm{g} / \mathrm{mL})$ it stimulated the release of NOx to a value of $0.566 \mu \mathrm{M}$, while the weakest action was found for compound 22, which at the highest concentration stimulated the release of NOx to a level of $0.419 \mu \mathrm{M}$ (Figure 3).

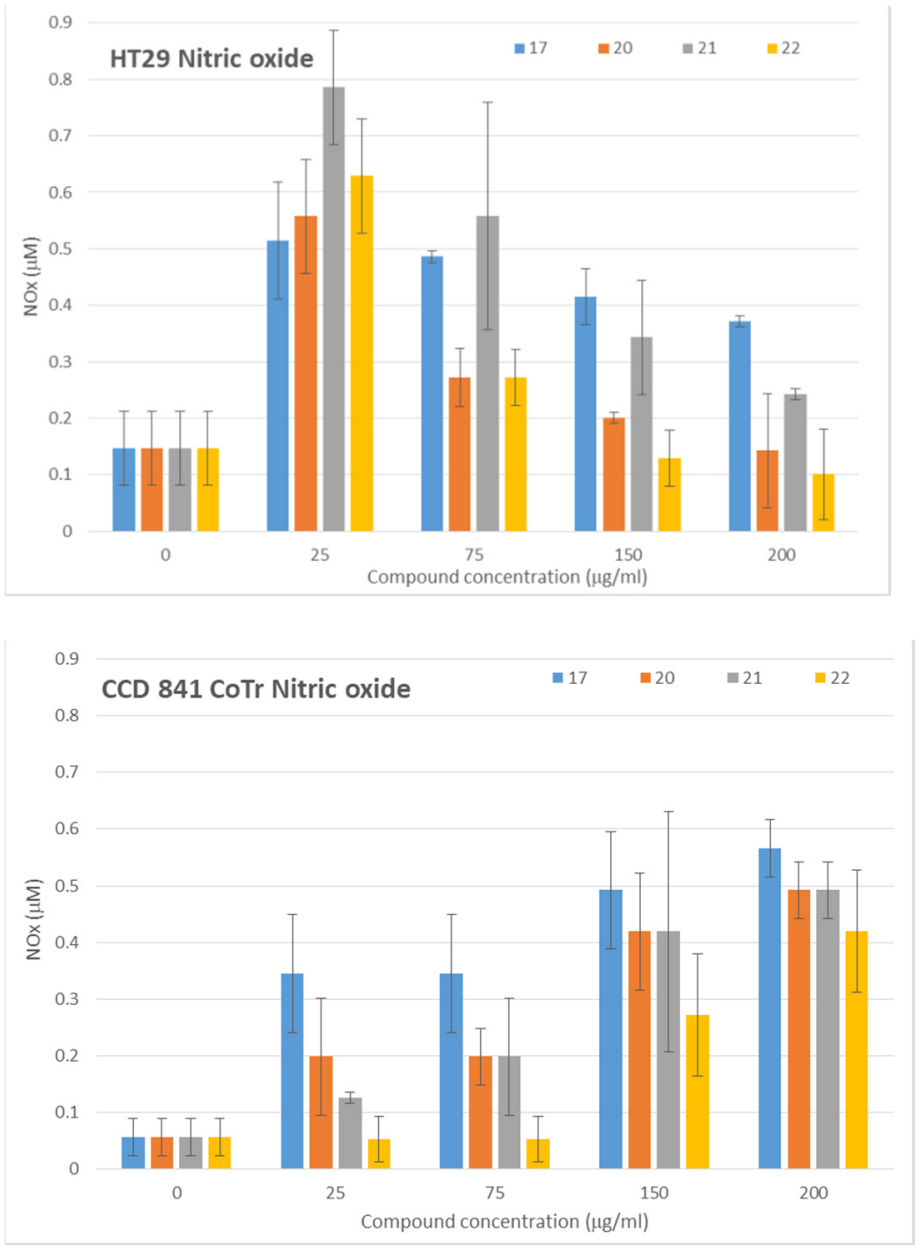

Figure 3. Nitric oxide (NO) measurement results for compounds 17, 20, 21, 22. HT29 Nitric oxide: human colon adenocarcinoma cell line (ATCC No. HTB-38) nitric oxide (NO) measurement results; CCD 841 CoTr Nitric oxide: human normal colon epithelial cells (ATCC No. CRL-1807) nitric oxide (NO) measurement results.

The reduction abilities of the tested compounds $(\mathbf{1 7}, \mathbf{2 0}, \mathbf{2 1}, \mathbf{2 2})$ were assessed by DPPH and FRAP methods. The results of the obtained studies were compared to known compounds with reductive activity, water-soluble synthetic vitamin E (Trolox) and ascorbic acid, respectively. In general, the tested compounds (17, 20, 21, 22) showed weak but 
detectable reductive activity. Compound 17 was the most effective, reducing the DPPH free radical at a concentration of $150 \mu \mathrm{g} / \mathrm{mL}$ which is equivalent to that of synthetic vitamin $\mathrm{E}$ at a concentration of $3.558 \pm 0.717 \mu \mathrm{g} / \mathrm{mL}$. The weakest reducing activity was observed for compound 20. On the other hand, compound 20 showed the strongest ferric-reducing power (FRAP), equal to $3.51 \pm 1.35 \mu \mathrm{g} / \mathrm{mL}$ of ascorbic acid activity. The weaker reducing activity of the $\mathrm{Fe}^{3+}$ ion was found for compound 22 (Tables 3 and 4).

Table 3. DPPH scavenging effect of tested compounds.

\begin{tabular}{|c|c|c|c|c|}
\hline \multirow{2}{*}{$\begin{array}{l}\text { Concentration } \\
(\mu \mathrm{g} / \mathrm{mL})\end{array}$} & \multicolumn{4}{|c|}{$\begin{array}{l}\text { Reduction Value, which Corresponds to the following Trolox } \\
\text { Concentration }(\mu \mathrm{g} / \mathrm{mL})\end{array}$} \\
\hline & 17 & 20 & 21 & 22 \\
\hline Control & 0 & 0 & 0 & 0 \\
\hline 25 & $2.037 \pm 0.210$ & $0.418 \pm 0.154$ & $0.264 \pm 0.256$ & $0.227 \pm 0.205$ \\
\hline 75 & $2.472 \pm 0.307$ & $0.748 \pm 0.512$ & $1.060 \pm 0.051$ & $0.336 \pm 0.263$ \\
\hline 150 & $3.558 \pm 0.717$ & $0.662 \pm 0.410$ & $1.241 \pm 0.102$ & $0.698 \pm 0.154$ \\
\hline 200 & $2.725 \pm 0.256$ & $0.879 \pm 0.768$ & $2.037 \pm 0.307$ & $1.205 \pm 0.870$ \\
\hline
\end{tabular}

The value of reduced DPPH radical by compounds $(\mathbf{1 7}, \mathbf{2 0}, \mathbf{2 1}, \mathbf{2 2})$ is compared to the control $(0 \%$ of reduction) As a control, methanol anhydrous, $99.8 \%$ was used. The results are presented as reduction values $(\mu \mathrm{g} / \mathrm{mL})$ corresponding to the appropriate concentration of Trolox.

Table 4. Ferric-reducing antioxidant power assay (FRAP) results of tested compounds.

\begin{tabular}{|c|c|c|c|c|}
\hline \multirow{2}{*}{$\begin{array}{l}\text { Concentration } \\
\quad(\mu \mathrm{g} / \mathrm{mL})\end{array}$} & \multicolumn{4}{|c|}{$\begin{array}{l}\text { Reduction Value, which Corresponds to the following-Ascorbic Acid } \\
\text { Concentration }(\mu \mathrm{g} / \mathrm{mL})\end{array}$} \\
\hline & 17 & 20 & 21 & 22 \\
\hline Control & 0 & 0 & 0 & 0 \\
\hline 25 & $0.81 \pm 0.54$ & $1.08 \pm 0.54$ & $0.54 \pm 0.01$ & $0.27 \pm 0.14$ \\
\hline 75 & $0.81 \pm 0.54$ & $1.89 \pm 0.27$ & $0.81 \pm 0.14$ & $0.81 \pm 0.27$ \\
\hline 150 & $1.08 \pm 0.54$ & $2.97 \pm 1.89$ & $1.35 \pm 0.54$ & $0.54 \pm 0.14$ \\
\hline 200 & $1.35 \pm 0.90$ & $3.51 \pm 1.35$ & $1.62 \pm 0.27$ & $0.81 \pm 0.14$ \\
\hline
\end{tabular}

The value of conversed Fe (III) to Fe (II) by compounds $(\mathbf{1 7}, \mathbf{2 0}, \mathbf{2 1}, \mathbf{2 2})$ is compared to the control $(0 \%$ of reduction) As a control, methanol anhydrous, $99.8 \%$ was used. The results are presented as reduction values $(\mu \mathrm{g} / \mathrm{mL})$ corresponding to the appropriate concentration of ascorbic acid.

May-Grünwald-Giemsa (MGG) cell staining was designed to evaluate cell morphology after incubation for $24 \mathrm{~h}$ with compounds 17, 20, 21 and 22. The performed observations are in line with the quantitative results obtained with the NR method. The activity of compounds determined to be cytotoxic in NR uptake assay, in MGG staining in both normal and neoplastic cells was observed as a decrease in the number of stained cells due to the detachment of dying cells from the carrier surface. In addition, you can also observe the detachment of cells from each other, their shrinkage as well as loss of intercellular interaction (Figure S9; Supplementary Materials).

\subsection{Molecular Docking}

In order to predict the target enzymes for most active compounds $(5,13,17,25)$ and to evaluate the possible interactions, a molecular docking study was carried out with the use of the Autodock Vina 4.2 [52]. Structures of compounds 13 and 25 are chemically related to widespread chemotherapeutic agents, which contain 5-nitrofuran moieties, such as Furazolidone, Nitrofurazone, and Nifuroxazide [53]. That is why it is logical to suppose that synthesized compounds may have the same mode of antibacterial action. This purpose is also confirmed by the fact that the structurally related compounds with 5-nitrophenyl moiety 10 and 22 do not possess any antimicrobial activity. The 5-nitrofuran derivatives have to be activated before mediating its cytotoxic effects. Reactions of activations are 
catalyzed by nitroreductase (NTR) enzymes. As a result, the production of free radicals is observed. They can readily react with cellular macromolecules, and they are directly responsible for antibacterial action. As a result, lipids oxidation, cell membrane damages, enzyme inactivation, and finally fragmentation of the DNA sequence is observed [54]. That is why we evaluated the binding energy of compounds $\mathbf{5}$ and $\mathbf{1 7}$ for Escherichia coli Nitroreductase (PDB code: 1YKI) and compare them with such energy for native ligand Nitrofurazone. Additionally, we made a cross-docking simulation with the nitrofurantoin, which was used as the reference compound in the microbiology assays. The dihydrofolate reductase (S. aureus, PDB code: 5ISP) and tyrosyl-tRNA synthetase (S. aureus, PDB code: 1JIJ) were also selected for in silico docking simulations of antibacterial activity of the most active compounds $(5,13,17,25)$.

Docking demonstrated that compounds $\mathbf{1 3}$ and $\mathbf{2 5}$ have a better affinity to Nitroreductase compared to Nitrofurazone (Table 5).

Table 5. Binding energies for compounds 13 and 25 (Escherichia coli Nitroreductase PDB code: 1YKI).

\begin{tabular}{ccccc}
\hline Compound & $\mathbf{1 3}$ & $\mathbf{2 5}$ & Nitrofurazone & Nitrofuratoin \\
\hline Binding Energy $(\mathrm{kcal} / \mathrm{mol})$ & -7.1 & -8.5 & -6.5 & -7.3 \\
\hline
\end{tabular}

As shown in Figure 4, compound 13 linked tightly with amino acid residues of

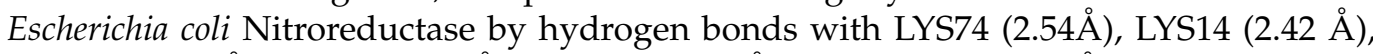

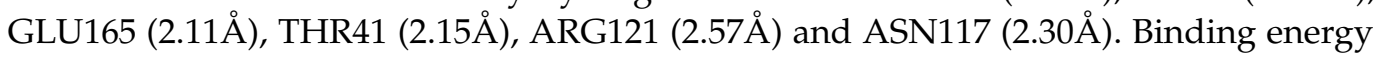
also increases owing to additional stabilized forces, such as van der Waals, attractive charge and amide-Pi stacked interactions between molecule and ASN42, GLU165 and THR41, respectively.

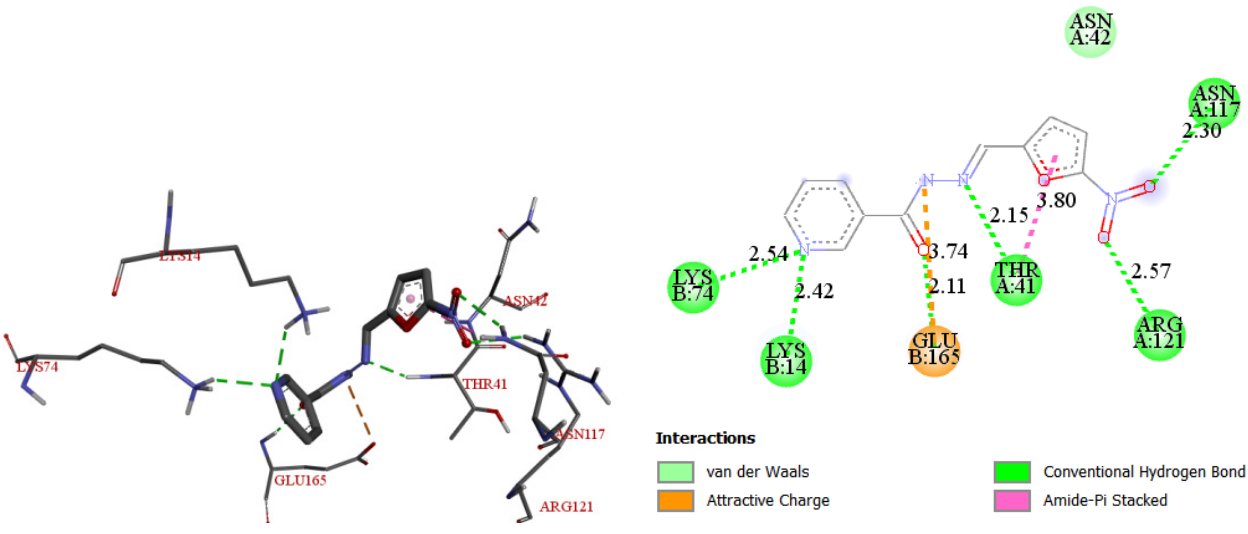

Figure 4. Docked conformation of compound 13 with Nitroreductase (PDB code: 1YKI).

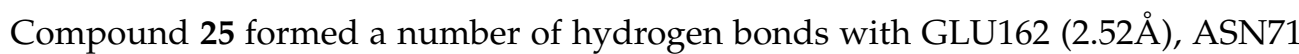

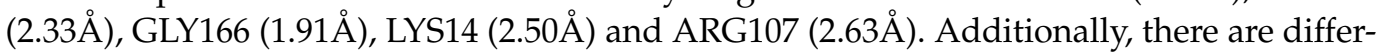
ent forms of hydrophobic interaction between PHE 124, ASN42 and GLU102.

It is quite similar to the interaction between Nitrofurazone and the Nitroreductase active site, where planar medicine molecule also makes several hydrogen bonds with the protein [55]. Docking results allowed us to suppose that compounds $\mathbf{1 3}$ and $\mathbf{2 5}$ would be more attractive substrates for Nitroreductase of $S$. aureus and interesting scaffold for new 5-nitrofuran derivatives with a wide spectrum of antimicrobial activities (Figure 5). 

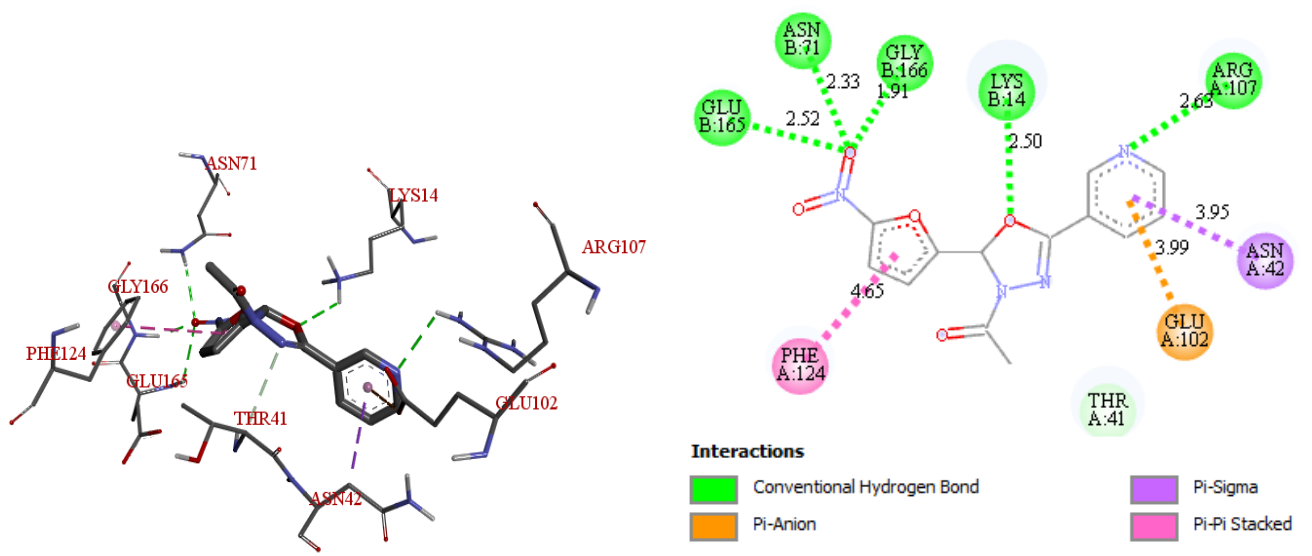

Figure 5. Docked conformation of compound 25 with Nitroreductase (PDB code: 1YKI).

Compounds $\mathbf{5}$ and $\mathbf{1 7}$ have quite a good affinity to target enzymes, nevertheless, those energies are smaller when compared to binding energies of initial ligands. Docking results allow suggesting that antimicrobial activity of substances $\mathbf{5}$ and $\mathbf{1 7}$ is connected mainly with inhibition of tyrosyl-tRNA synthetase. The most active compounds (13 and 25) showed good affinity to tyrosyl-tRNA synthetase and it is correlated with their wide activity against either Gram-positive or Gram-negative bacteria strains. The binding energies are shown in Table 6.

Table 6. The binding energies for compounds 5, 13, 17 and 25 to dihydrofolate reductase (PDB code: 5ISP) and tyrosyl-tRNA synthetase (PDB code: 1JIJ).

\begin{tabular}{ccccccc}
\hline Comp./PDB code: & $\mathbf{5}$ & $\mathbf{1 7}$ & $\begin{array}{c}\text { Ligand } \\
\text { (UCP1106) }\end{array}$ & $\mathbf{1 3}$ & $\mathbf{2 5}$ & $\begin{array}{c}\text { Ligand } \\
\text { (SB-239629) }\end{array}$ \\
\hline 5ISP & -7.5 & -7.7 & -9.5 & -6.9 & -8.2 & - \\
\hline 1JIJ & -8.4 & -8.2 & - & -8.8 & -8.9 & -8.7 \\
\hline
\end{tabular}

The planar molecule of compound 5 occupies hydrophobic pockets, made by LEU8, VAL31 and LEU54. Additionally, three amino acids have alkyl interactions with iodine substituent of the phenyl ring (TYR98, ILE14 and VAL6) (Figure 6).
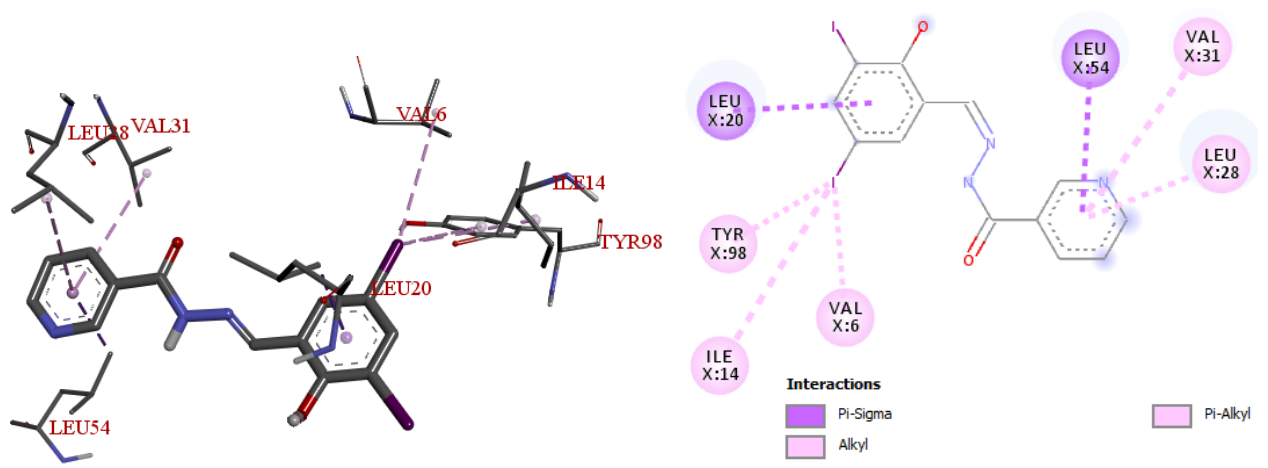

Figure 6. The interaction between compound 5 and tyrosyl-tRNA synthetase (PDB code: 1YKI).

Compound 17 makes the several alkyl interactions with aliphatic aminoacids LEU20, ALA7, VAL20 and VAL31, also by the iodine atoms, but the lack of hydrogen bond interaction decreases the affinity of compounds 5 and $\mathbf{1 7}$ with tyrosyl-tRNA synthetase, compared to the reference ligand SB-239629 (Figure 7) [56]. 


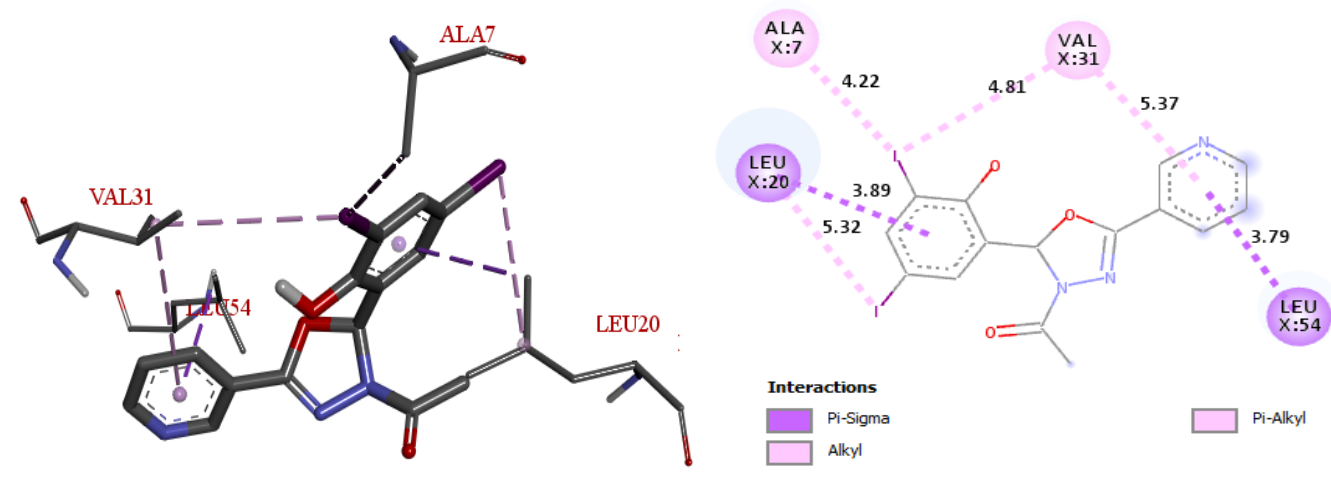

Figure 7. The interaction between compound $\mathbf{1 7}$ and tyrosyl-tRNA synthetase (PDB code: 1YKI).

An appropriate ADMET profile for new compounds is often crucial for further development as new potential antimicrobial agents. Modern in silico techniques allow simplifying the search for new chemical entities with suitable physicochemical properties for efficient and safe oral administration. The Lipinski rule of five become the non-official standard in medicinal chemistry. Therefore, ADMET profile predictions were made for 5, 13, 17 and 25 using freely accessible portals SwissADME and ProTOX. Additionally, ciprofloxacin and nitrofurantoin were chosen as the reference compounds for comparison. Results are highlighted in Table 7.

Table 7. Predicted properties of the most active compounds and two reference chemotherapeutics.

\begin{tabular}{|c|c|c|c|c|c|c|c|c|}
\hline Compounds & $\mathbf{M W}^{\mathrm{a}}$ & TPSA $^{\mathbf{b}}$ & $X \log P c$ & $\mathrm{GA}^{\mathrm{d}}$ & BBB $^{e}$ & $\operatorname{LR}^{\mathrm{f}}$ & TC $\mathrm{g}$ & $\mathrm{LD}_{50} \mathrm{~h}$ \\
\hline 5 & 493.04 & 74.58 & 2.71 & High & Yes & Yes & 4 & 375 \\
\hline 13 & 260.21 & 113.31 & 1.39 & High & No & Yes & 4 & 1500 \\
\hline 17 & 535.08 & 75.02 & 2.82 & High & Yes & $\begin{array}{c}\text { Yes, } 1 \\
\text { violation }\end{array}$ & 5 & 2930 \\
\hline 25 & 302.24 & 113.75 & 1.14 & High & No & Yes & 5 & 3200 \\
\hline Ciprofloxacin & 331.34 & 74.57 & -1.08 & High & No & Yes & 4 & 2000 \\
\hline Nitrofurantoin & 238.16 & 120.73 & -0.47 & High & No & Yes & 4 & 1000 \\
\hline
\end{tabular}

According to obtained data, compounds 5, 13, 17 and 25 possess suitable ADMET profiles, which allows us to suggest them as the perspective antimicrobial agents.

\section{Discussion}

The condensation reaction is a simple method by which acylhydrazones (2-13) can be obtained quickly. Then, the cyclization reaction in acetic anhydride of obtained compounds enabled the synthesis of 3-acetyl-2,5-disubstituted-1,3,4-oxadiazoline derivatives. The ease of this synthesis, good yield results and high biological potential of the obtained derivatives encourage the search for compounds of antimicrobial nature among them. Among the compounds from the group of acylhydrazones, a substance with the 5-nitrofuran substituent showed the highest activity. It showed high activity especially against Gram-positive bacterial strains, among them towards Staphylococcus epidermidis (MIC $=1.95 \mu \mathrm{g} / \mathrm{mL}$ ), Staphylococcus aureus ATCC 6538 (MIC $=3.91 \mu \mathrm{g} / \mathrm{mL}$ ) and also against the MRSA strain (MIC $=7.81 \mu \mathrm{g} / \mathrm{mL}$ ). The 1,3,4-oxadiazoline derivative, i.e., the compound numbered as 25 , showed half of the activity (MIC $=15.62 \mu \mathrm{g} / \mathrm{mL}$ ) against the same strains. Similarly, compound 5 with the 2-hydroxy-3,5-diiodophenyl substituent after conversion to 1,3,4oxadiazoline derivative showed half of the activity against the same bacterial strains. On 
the basis of obtained results, it can be concluded that the nicotinic acid-derived acylhydrazones are more active than the corresponding 1,3,4-oxadiazoline derivatives in terms of antibacterial activity against Gram-positive bacteria. On the other hand, the activity against fungal strains was different. In this case, the 3-acetyl-1,3,4-oxadiazolines were more active towards yeasts than acylhydrazones. This fact can be observed in the example of the compounds with the 5-nitrofuran substituent, i.e., 13 (acylhydrazone) and 25 (1,3,4oxadiazoline derivative). The substance 25 showed good activity against Candida albicans ATCC 10231 (MIC $=15.62 \mu \mathrm{g} / \mathrm{mL}$ ), while compound 13 showed no activity.

Analysis of the results of the conducted research in terms of the structure-activity relationship (SAR), it can be stated that acylhydrazones showed greater biological activity in relation to $\mathrm{N}$-acetyl-1,3,4-oxadiazolines. The most active of the two groups were those derivatives that had the 5 -nitrofuran substituent. We saw a similar situation in our previous articles [57-61, where, the cyclization process also resulted in a decrease in the activity of the tested compounds. Thus, it can be concluded that the introduction of a 1,3,4-oxadiazole ring into the molecule deteriorates the antimicrobial activity, and the 5-nitro-furoyl moiety significantly improves the effectiveness against bacteria and fungi.

Moreover, the tested acylhydrazones were significantly more active against Grampositive bacteria than against Gram-negative bacteria. This difference can be seen perfectly during the analysis of the activity of compound $\mathbf{5}$ with a 2-hydroxy-3,5-diiodophenyl substituent, where the activity against Gram-positive bacteria was within the limits of $\mathrm{MIC}=7.81-15.62 \mu \mathrm{g} / \mathrm{mL}$ and the activity against Gram-negative was observed only for one strain-Bordetella bronchiseptica ATCC $4617(\mathrm{MIC}=62.5 \mu \mathrm{g} / \mathrm{mL})$, and the others substances were not active. A similar difference in activity was observed for the compound numbered 13 with a 5-nitrofuran substituent. It was the most active against Gram-positive bacteria Staphylococcus epidermidis ATCC 12228 (MIC $=1.95 \mu \mathrm{g} / \mathrm{mL}$ ), and against the remaining Gram-positive, it also showed high activity (MIC $=1.95-15.62 \mu \mathrm{g} / \mathrm{mL}$ ). On the other hand, against Gram-negative strains, activity was either good or moderate. The activity of $\mathrm{N}$ acetyl-1,3,4-oxadiazolines was similar to acylhydrazones. They also showed greater activity against Gram-positive than towards Gram-negative bacteria. The most active of this group was compound numbered as 25 against Gram-positive strains at $(\mathrm{MIC}=7.81-62.5 \mu \mathrm{g} / \mathrm{mL}$ ), while for Gram-negative bacteria the range of activity was MIC $=62.5-250 \mu \mathrm{g} / \mathrm{mL}$. Additionally, for compound 17, the measured activity against Gram-positive bacteria was MIC $=7.81-62.5 \mu \mathrm{g} / \mathrm{mL}$, and no activity was found towards Gram-negative strains.

In conclusion, the results showed slightly different activity of the newly synthesized compounds against Gram-positive and Gram-negative bacteria. Among them, compounds $5,13,17$ and 25 had a satisfactory and beneficial activity with strong or good effect towards all reference Gram-positive bacteria. In turn, microorganisms belong to bacteria from Enterobacterales and non-fermenting rods were less sensitive to these substances. Only substances $\mathbf{1 3}$ and $\mathbf{2 5}$ showed some activity with moderate or good effects depending on the microorganism. Due to the distinctive structure of the cell wall, Gram-negative bacteria are usually more resistant to antibiotics or other antibacterial interventions than Gram-positive. Their cell membrane is thin but difficult to penetrate. Therefore, these bacteria are harder to kill [57]. Our results also confirm this relationship.

\section{Materials and Methods}

\subsection{Chemistry}

All reagents used for the experiments were purchased from Merck Co. (Darmstadt, Germany) and used without further purification. They had a class of purity declared by the manufacturer. The melting points of the obtained compounds were determined with a Fisher-Johns apparatus (Fisher Scientific, Schwerte, Germany), and presented without any correction. The purity of the obtained compounds was assessed through thin layer chromatography (TLC) on plates covered with silica gel (aluminium oxide 60 F-254) by Merck. Chloroform-ethanol mixtures in the ratio 10:1 $(v / v)$ were used as the mobile phase. Spots were developed by irradiation with UV light with a wavelength $\lambda=254 \mathrm{~nm}$. The 
FT-IR spectra were recorded on a Nicolet 6700 spectrometer (Thermo Scientific, Madison, Wisconsin, USA) in $\mathrm{cm}^{-1}$. The ${ }^{1} \mathrm{H}$ and ${ }^{13} \mathrm{C}$ NMR spectra were recorded on the Bruker Avance 300 and 600 apparatus (Bruker BioSpin GmbH, Ettlingen, Germany). The compounds were dissolved in dimethyl sulfoxide $\left(\mathrm{DMSO}_{-{ }_{6}}\right)$ before analysis. Tetramethylsilane (TMS) was used as an internal standard. Chemical shift values are given in ppm. Elemental analysis was determined by a Perkin Elmer 2400 Series II CHNS/O analyzer (Waltham, MA, USA), and the results were within $\pm 0.4 \%$ of the theoretical values.

\subsubsection{Synthesis of Acylhydrazones of Nicotinic Acid Hydrazide (2-13)}

New acylhydrazones of nicotinic acid (2-13) were obtained on the basis of the procedure reported earlier [58-62]. The nicotinic acid hydrazide (1) (0.01 mole) was dissolved in $20 \mathrm{~mL}$ of ethanol (96\%) and appropriate aldehyde $(0.011$ mole) was added. The mixture was heated under reflux for $3 \mathrm{~h}$. Subsequently, the solution was allowed to cool and placed in the refrigerator for $24 \mathrm{~h}$. The precipitate was filtered off and recrystallized from ethanol.

Physicochemical properties of acylhydrazones of nicotinic acid (2-13):

$N$-[(4-tert-butylphenyl)methylidene]pyridine-3-carbohydrazide (2)

White powder, yield: 87\%, M.p.: $116{ }^{\circ} \mathrm{C}$; IR: 3443, 3220 (N-H), 3031 (CH, arom.), 2958 (CH, aliph.), 1647 (C=O), 1563 (C=N), 1295, 1151 (C-OC), 1028 (N-N); ${ }^{1} \mathrm{H}$ NMR (600 MHz, DMSO-d 6 ) $\delta$ (ppm): $1.31\left(\mathrm{~s}, 9 \mathrm{H}, 3 \mathrm{xCH}_{3}\right), 7.50-7.51(\mathrm{~d}, 2 \mathrm{H}, \mathrm{ArH}, J=6 \mathrm{~Hz})$, 7.57-7.59 (m, 1H, ArH), 7.68-7.69 (d, 1H, ArH, J = 6 Hz), 8.25-8.27 (m, 1H, ArH), 8.43 (s, $1 \mathrm{H},=\mathrm{CH}), 8.77-8.78(\mathrm{~m}, 1 \mathrm{H}, \mathrm{ArH}), 9.06-9.07$ (m, 1H, ArH), $11.98(\mathrm{~s}, 1 \mathrm{H}, \mathrm{NH}) ;{ }^{13} \mathrm{C} \mathrm{NMR}$ (150 MHz, DMSO-d $\left.d_{6}\right) \delta(\mathrm{ppm}): 31.78\left(3 \mathrm{xCH}_{3}\right), 35.70\left(\mathrm{C}_{\text {t-butyl }}\right), 124.06,126.15,127.51,129.71$, $131.88\left(7 \mathrm{C}_{\mathrm{ar}}\right), 135.88(=\mathrm{CH}), 148.87,149.02,152.70,153.57\left(4 \mathrm{C}_{\mathrm{ar}}\right), 162.07(\mathrm{C}=\mathrm{O})$; Anal. calc. for $\mathrm{C}_{17} \mathrm{H}_{19} \mathrm{ClN}_{3} \mathrm{O}$ (281.35) (\%): C 72.57; H 6.81; N 14.94. Found: C 77.25; H 6.31; N 14.50.

$\mathrm{N}$-[(3-bromo-4-hydroxyphenyl)methylidene]pyridine-3-carbohydrazide (3)

White powder, yield: 93\%, M.p.: $260{ }^{\circ} \mathrm{C}$; IR: $3458(\mathrm{OH}), 3189$ (N-H), 3021 (CH, arom.), 2970 (CH, aliph.), 1636 (C=O), 1597 (C=N), 1229, 1080 (C-OC), 1017 (N-N); ${ }^{1} \mathrm{H}$ NMR $\left(600 \mathrm{MHz}, \mathrm{DMSO}-d_{6}\right) \delta$ (ppm): 7.49-7.51 (m, 1H, ArH), 7.56-7.59 (m, 1H, ArH), 7.94 (s, $1 \mathrm{H}, \mathrm{OH}), 8.15-8.16(\mathrm{~m}, 1 \mathrm{H}, \mathrm{ArH}), 8.24-8.26$ (m, 1H, ArH), 8.30 (s, 1H, =CH), 8.69-8.70 (m, 1H, ArH), 8.77-8.78 (m, 1H, ArH), 9.06-9.07 (d, 1H, ArH, J = 6 Hz), 12.13 (s, 1H, NH); ${ }^{13} \mathrm{C}$ NMR (150 MHz, DMSO-d 6 ) $\delta$ (ppm): 112.69, 124.05, 129.14, 129.30, 129.53, 131.21, 135.13 $\left(7 \mathrm{C}_{\mathrm{ar}}\right), 135.94(=\mathrm{CH}), 145.83,149.05,152.23,152.78\left(4 \mathrm{C}_{\mathrm{ar}}\right), 162.20(\mathrm{C}=\mathrm{O})$; Anal. calc. for $\mathrm{C}_{13} \mathrm{H}_{10} \mathrm{BrN}_{3} \mathrm{O}_{2}$ (320.14) (\%): C 48.77; H 3.15; N 24.96. Found: C 49.25; H 3.31; N 25.50.

$\mathrm{N}$-[(3,5-dibromo-4-hydroxyphenyl)methylidene]pyridine-3-carbohydrazide (4)

White powder, yield: 92\%, M.p.: $242{ }^{\circ} \mathrm{C}$; IR: $3528(\mathrm{OH}), 3294(\mathrm{~N}-\mathrm{H}), 3062$ (CH, arom.), 2970 (CH, aliph.), 1651 (C=O), 1597 (C=N), 1293, 1067 (C-OC), 1029 (N-N); ${ }^{1} \mathrm{H}$ NMR $\left(600 \mathrm{MHz}, \mathrm{DMSO}-d_{6}\right) \delta(\mathrm{ppm}): 7.03-7.04(\mathrm{~d}, 1 \mathrm{H}, \mathrm{ArH}, J=6 \mathrm{~Hz}), 7.56-7.60(\mathrm{~m}, 1 \mathrm{H}, \mathrm{ArH})$, 7.88-7.89 (d, 1H, ArH, $J=6 \mathrm{~Hz}), 8.24-8.26$ (m, 1H, ArH), 8.31 (s, 1H, =CH), 8.76-8.77 (m, 1H, ArH), 9.05-9.06 (d, 1H, ArH, J = 6 Hz), 10.85 (s, 1H, OH), 11.97 (s, 1H, NH); ${ }^{13} \mathrm{C}$ NMR (150 MHz, DMSO-d 6 ) $\delta$ (ppm): 110.31, 117.03, 124.05, 127.30, 128.47, 129.69, 131.97 $\left(7 \mathrm{C}_{\mathrm{ar}}\right), 135.87(=\mathrm{CH}), 147.53,149.00,152.68,156.45\left(4 \mathrm{C}_{\mathrm{ar}}\right), 162.00(\mathrm{C}=\mathrm{O})$; Anal. calc. for C13H9Br ${ }_{2} \mathrm{~N}_{3} \mathrm{O}_{2}$ (399.04) (\%): C 39.13; H 2.27; N 10.53. Found: C 39.27; H 2.31; N 10.83.

$N$-[(2-hydroxy-3,5-diiodophenyl)methylidene]pyridine-3-carbohydrazide (5)

Yellow powder, yield: 89\%, M.p.: $222{ }^{\circ} \mathrm{C}$; IR: $3426(\mathrm{OH}), 3221(\mathrm{~N}-\mathrm{H}), 3016(\mathrm{CH}$, arom.), 2970 (CH, aliph.), 1652 (C=O), $1513(\mathrm{C}=\mathrm{N}), 1272,1045$ (C-OC), $1022(\mathrm{~N}-\mathrm{N}) ;{ }^{1} \mathrm{H}$ NMR $\left(600 \mathrm{MHz}, \mathrm{DMSO}-d_{6}\right) \delta$ (ppm): 7.60-7.62 (m, 1H, ArH), 7.93-7.94 (d, 1H, ArH, J = 6 Hz), 8.07-8.08 (d, 1H, ArH, $J=6$ Hz), 8.29-8.30 (m, 1H, ArH), 8.45 (s, 1H, =CH), 8.80-8.81 (m, 1H, ArH), 9.10-9.11 (d, 1H, ArH, J = 6 Hz), 12.71 (s, 1H, OH), $12.82(\mathrm{~s}, 1 \mathrm{H}, \mathrm{OH}) ;{ }^{13} \mathrm{C}$ NMR (150 MHz, DMSO-d 6 ) $\delta$ (ppm): 82.65, 88.29, 120.70, 124.16, $128.56\left(5 \mathrm{C}_{\mathrm{ar}}\right), 136.08$ $(=\mathrm{CH}), 139.36,147.18,148.20,149.18,153.22,157.11\left(6 \mathrm{C}_{\mathrm{ar}}\right), 162.17(\mathrm{C}=\mathrm{O})$; Anal. calc. for $\mathrm{C}_{13} \mathrm{H}_{9} \mathrm{I}_{2} \mathrm{~N}_{3} \mathrm{O}_{2}$ (493.04) (\%): C 31.67; H 1.84; N 8.52. Found: C 32.15; H 1.96; N 8.74.

$\mathrm{N}$-[2-(2-bromo-3-hydroxy-4-methoxyphenyl)ethylidene]pyridine-3-carbohydrazide (6)

Grey powder, yield: 91\%, M.p.: $220^{\circ} \mathrm{C}$; IR: $3522(\mathrm{OH}), 3163$ (N-H), 3003 (CH, arom.), 2967 (CH, aliph.), 1641 (C=O), 1491 (C=N), 1251, 1063 (C-OC), 1028 (N-N); ${ }^{1} \mathrm{H}$ NMR 
(600 MHz, DMSO-d 6 ) $\delta(\mathrm{ppm}): 3.90\left(\mathrm{~s}, 3 \mathrm{H}, \mathrm{CH}_{3}\right), 7.11-7.12(\mathrm{~d}, 1 \mathrm{H}, \mathrm{ArH}, J=6 \mathrm{~Hz}), 7.53-7.54$ $(\mathrm{d}, 1 \mathrm{H}, \mathrm{ArH}, J=6 \mathrm{~Hz}), 7.57-7.59$ (m, 1H, ArH), 8.26-8.28 (m, 1H, ArH), 8.76-8.77 (d, 1H, $\mathrm{ArH}, J=6 \mathrm{~Hz}), 8.78(\mathrm{~s}, 1 \mathrm{H},=\mathrm{CH}), 9.08-9.09(\mathrm{~d}, 1 \mathrm{H}, \mathrm{ArH}, J=6 \mathrm{~Hz}), 9.71(\mathrm{~s}, 1 \mathrm{H}, \mathrm{OH}), 12.12$ (s, $1 \mathrm{H}, \mathrm{NH}) ;{ }^{13} \mathrm{C}$ NMR $\left(150 \mathrm{MHz}, \mathrm{DMSO}-d_{6}\right) \delta$ (ppm): 111.50, 112.52, 118.25, 124.03, 126.17, $129.60\left(6 \mathrm{C}_{\mathrm{ar}}\right), 135.89$ (=CH), 144.24, 147.99, 149.06, 150.20, $152.73\left(5 \mathrm{C}_{\mathrm{ar}}\right), 162.01(\mathrm{C}=\mathrm{O})$; Anal. calc. for $\mathrm{C}_{15} \mathrm{H}_{14} \mathrm{BrN}_{3} \mathrm{O}_{3}$ (364.19 (\%): C 49.47; $\mathrm{H}$ 3.87; $\mathrm{N}$ 11.54. Found: $\mathrm{C} 49.25 ; \mathrm{H} 3.51$; N 11.50.

N-[(2-bromo-5-fluorophenyl)methylidene]pyridine-3-carbohydrazide (7)

White powder, yield: 95\%, M.p.: $128^{\circ} \mathrm{C}$; IR: 3442, 3190 (N-H), 3056 (CH, arom.), 2970 (CH, aliph.), 1656 (C=O), $1570(\mathrm{C}=\mathrm{N}), 1297,1103$ (C-OC), 1028 (N-N); ${ }^{1} \mathrm{H}$ NMR (600 MHz, DMSO- $\left.d_{6}\right) \delta$ (ppm): 7.30-7.33 (m, 1H, ArH), 7.59-7.61 (m, 1H, ArH), 7.71-7.73 (m, 1H, ArH), 7.76-7.79 (m, 1H, ArH), 8.28-8.30 (m, 1H, ArH), 8.78 (s, 1H, =CH), 8.79-8.80 (m, 1H, ArH), 9.10-9.11 (m, 1H, ArH), 12.38 (s, 1H, NH); ${ }^{13} \mathrm{C}$ NMR (150 MHz, DMSO-d 6 ) $\delta$ (ppm): 113.62, $113.78,118.66,119.70,124.10,129.25,135.56,135.61\left(8 \mathrm{C}_{\mathrm{ar}}\right), 135.99(=\mathrm{CH}), 146.04,149.12$, $153.00\left(3 \mathrm{C}_{\mathrm{ar}}\right), 162.34(\mathrm{C}=\mathrm{O})$; Anal. calc. for $\mathrm{C}_{13} \mathrm{H}_{9} \mathrm{BrFN}_{3} \mathrm{O}(322.13)(\%): \mathrm{C} 48.47 ; \mathrm{H} 2.82 ; \mathrm{N}$ 13.04. Found: C 49.27; H 2.92; N 13.50.

$\mathrm{N}$-[(4-bromo-2-fluorophenyl)methylidene]pyridine-3-carbohydrazide (8)

Grey powder, yield: 85\%, M.p.: $168{ }^{\circ} \mathrm{C}$; IR: 3374, 3179 (N-H), 3047 (CH, arom.), 2967(CH, aliph.), 1647 (C=O), 1556 (C=N), 1290, 1068 (C-OC), 1025 (N-N); ${ }^{1} \mathrm{H}$ NMR $\left(600 \mathrm{MHz}, \mathrm{DMSO}-d_{6}\right) \delta$ (ppm): 7.54-7.56 (m, 1H, ArH), 7.58-7.60 (m, 1H, ArH), 7.70-7.72 $(\mathrm{m}, 1 \mathrm{H}, \mathrm{ArH}), 7.89-7.91(\mathrm{t}, 1 \mathrm{H}, \mathrm{ArH}, J=6 \mathrm{~Hz}), 8.26-8.28(\mathrm{~m}, 1 \mathrm{H}, \mathrm{ArH}), 8.63(\mathrm{~s}, 1 \mathrm{H}$, $=\mathrm{CH}), 8.78-8.79(\mathrm{~m}, 1 \mathrm{H}, \mathrm{ArH}), 9.08-9.09(\mathrm{~d}, 1 \mathrm{H}, \mathrm{ArH}, J=6 \mathrm{~Hz}), 12.20(\mathrm{~s}, 1 \mathrm{H}, \mathrm{ArH}) ;{ }^{13} \mathrm{C}$ NMR (150 MHz, DMSO-d 6 ) $\delta$ (ppm): 119.88, 120.04, 121.67, 124.13, 128.26, 128.85, 129.35 $\left(7 \mathrm{C}_{\mathrm{ar}}\right), 135.93(=\mathrm{CH}), 140.69,149.06,152.94,160.09\left(4 \mathrm{C}_{\mathrm{ar}}\right), 162.18(\mathrm{C}=\mathrm{O})$; Anal. calc. for $\mathrm{C}_{13} \mathrm{H}_{9} \mathrm{BrFN}_{3} \mathrm{O}$ (322.13) (\%): C 48.47; H 2.82; N 13.04. Found: C 48.99; H 3.13; N 12.99.

$\mathrm{N}$-[(2-chloro-6-fluorophenyl)methylidene]pyridine-3-carbohydrazide (9)

White powder, yield: 88\%, M.p.: $186{ }^{\circ} \mathrm{C}$; IR: 3462,3183 (N-H), 3028 (CH, arom.), 2970 (CH, aliph.), 1739 (C=O), $1601(\mathrm{C}=\mathrm{N}), 1227,1070$ (C-OC), $1036(\mathrm{~N}-\mathrm{N}) ;{ }^{1} \mathrm{H}$ NMR $(600 \mathrm{MHz}$, DMSO- $\left.d_{6}\right) \delta$ (ppm): 7.35-7.38 (m, 1H, ArH), 7.44-7.46 (d, 1H, ArH, $J=12$ Hz), 7.49-7.53 $(\mathrm{m}, 1 \mathrm{H}, \mathrm{ArH}), 7.58-7.60(\mathrm{~m}, 1 \mathrm{H}, \mathrm{ArH}), 8.28-8.29$ (d, 1H, ArH, $J=6 \mathrm{~Hz}), 8.71(\mathrm{~s}, 1 \mathrm{H},=\mathrm{CH})$, 8.79-8.80 (d, 1H, ArH, $J=6 \mathrm{~Hz}), 9.09-9.10(\mathrm{~d}, 1 \mathrm{H}, \mathrm{ArH}, J=6 \mathrm{~Hz}), 12.24(\mathrm{~s}, 1 \mathrm{H}, \mathrm{NH}) ;{ }^{13} \mathrm{C}$ NMR (150 MHz, DMSO-d 6 ) $\delta$ (ppm): 116.05, 116.20, 124.09, 126.58, 129.37, 132.34, 134.41 $\left(7 \mathrm{C}_{\mathrm{ar}}\right), 135.99(=\mathrm{CH}), 142.28,149.12,152.92,159.82\left(4 \mathrm{C}_{\mathrm{ar}}\right), 162.21(\mathrm{C}=\mathrm{O})$; Anal. calc. for $\mathrm{C}_{13} \mathrm{H}_{9} \mathrm{ClFN}_{3} \mathrm{O}$ (277.68) (\%): C 56.23; H 3.27; N 15.13. Found: C 55.89; H 3.31; N 15.23.

$\mathrm{N}$-[(2-chloro-5-nitrophenyl)methylidene]pyridine-3-carbohydrazide (10)

White powder, yield: 87\%, M.p.: $220{ }^{\circ} \mathrm{C}$; IR: 3296 (N-H), 3098 (CH, arom.), 2927 (CH, aliph.), 1663 (C=O), 1508 (C=N), 1298, 1042 (C-OC), $1022(\mathrm{~N}-\mathrm{N}) ;{ }^{1} \mathrm{H}$ NMR (600 MHz, DMSO- $\left.d_{6}\right) \delta(\mathrm{ppm}):$ 7.60-7.62 (m, 1H, ArH), 7.86-7.88 (d, 1H, ArH, J = 12 Hz), 8.26-8.28 (m, $1 \mathrm{H}, \mathrm{ArH}), 8.30-8.31$ (m, 1H, ArH), 8.73-8.74 (d, 1H, ArH, J = 6 Hz), 8.80-8.81 (m, 1H, ArH), $8.88(\mathrm{~s}, 1 \mathrm{H},=\mathrm{CH}), 9.11-9.12(\mathrm{~d}, 1 \mathrm{H}, \mathrm{ArH}, J=6 \mathrm{~Hz}), 12.45(\mathrm{~s}, 1 \mathrm{H}, \mathrm{NH}) ;{ }^{13} \mathrm{C} \mathrm{NMR}(150 \mathrm{MHz}$, DMSO- $\left.d_{6}\right) \delta$ (ppm): 121.66, 124.16, 125.88, 129.12, 132.11, $133.37\left(6 \mathrm{C}_{\mathrm{ar}}\right), 136.02$ (=CH), 139.66, 142.80, 147.21, 149.12, 153.11 (5C ar), $162.43(\mathrm{C}=\mathrm{O})$; Anal. calc. for $\mathrm{C}_{13} \mathrm{H}_{9} \mathrm{ClN}_{4} \mathrm{O}_{3}(304.69)$ (\%): C 51.25; H 2.98; N 18.39. Found: C 49.88; H 2.51; N 18.99.

$\mathrm{N}$-[(2,3-difluorophenyl)methylidene]pyridine-3-carbohydrazide (11)

White powder, yield: 96\%, M.p.: $146^{\circ} \mathrm{C}$; IR: 3385, 3167, (N-H), 3069 (CH, arom.), 2990 (CH, aliph.), 1664 (C=O), 1561 (C=N), 1299, 1081 (C-OC), 1029 (N-N); ${ }^{1} \mathrm{H}$ NMR (600 MHz, DMSO- $\left.d_{6}\right) \delta$ (ppm): 7.31-7.34 (m, 1H, ArH), 7.52-7.56 (m, 1H, ArH), 7.59-7.61 (m, 1H, ArH), 7.76-7.77 (m, 1H, ArH), 8.27-8.29 (d, 1H, ArH, J = 12 Hz), 8.68 (s, 1H, =CH), 8.79-8.80 (m, 1H, ArH), 9.09-9.10 (d, 1H, ArH, J = 6 Hz), 12,24 (s, 1H, NH); ${ }^{13} \mathrm{C}$ NMR $(150 \mathrm{MHz}$, DMSO- $\left.d_{6}\right) \delta$ (ppm): 119.15, 119.26, 122.11, 124.13, 124.50, 125.73, $129.31\left(7 \mathrm{C}_{\mathrm{ar}}\right), 135.95(=\mathrm{CH})$, $140.61,149.08,151.25,152.97\left(4 \mathrm{C}_{\mathrm{ar}}\right), 162.24(\mathrm{C}=\mathrm{O})$; Anal. calc. for $\mathrm{C}_{13} \mathrm{H}_{9} \mathrm{FN}_{3} \mathrm{O}(261.23)(\%)$ : C 59.77; H 3.47; N 16.09. Found: C 6.01; H 3.52; N 15.89.

$N$-\{[4-(pyrrolidin-1-yl)phenyl]methylidene\}pyridine-3-carbohydrazide (12) 
Yellow powder, yield: 88\%, M.p.: $164{ }^{\circ} \mathrm{C}$; IR: 3423, 3195 (N-H), 3046 (CH, arom.), 2970 (CH, aliph.), 1739 (C=O), 1595 (C=N), 1217, 1106 (C-OC), 1025 (N-N); ${ }^{1} \mathrm{H}$ NMR (600 MHz, DMSO- $\left.d_{6}\right) \delta(\mathrm{ppm}): 1.96-1.99\left(\mathrm{~m}, 8 \mathrm{H}, 4 \times \mathrm{CH}_{2-\text { pyrrolidine }}\right), 6.60-6.61(\mathrm{~d}, 1 \mathrm{H}, \mathrm{ArH}, J=6 \mathrm{~Hz})$, 6.63-6.65 (d, 2H, ArH, J = 12 Hz), 7.54-7.56 (d, 1H, ArH, J = 12 Hz), 7.67-7.69 (d, 2H, ArH, $J=12 \mathrm{~Hz}), 8.15-8.24(\mathrm{~m}, 1 \mathrm{H}, \mathrm{ArH}), 8.29(\mathrm{~s}, 1 \mathrm{H},=\mathrm{CH}), 9.65-9.66(\mathrm{~d}, 1 \mathrm{H}, \mathrm{ArH}, J=6 \mathrm{~Hz})$,

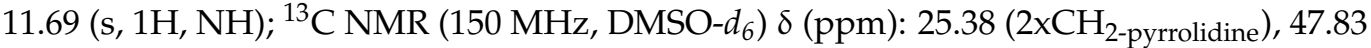
(2xCH 2-pyrrolidine), 111.74, 112.06, 123.94, 124.73, 129.18, 132.17, $135.11\left(9 \mathrm{C}_{\mathrm{ar}}\right), 148.53(=\mathrm{CH})$, $152.21\left(2 \mathrm{C}_{\mathrm{ar}}\right), 164.76(\mathrm{C}=\mathrm{O})$; Anal. calc. for $\mathrm{C}_{17} \mathrm{H}_{18} \mathrm{~N}_{4} \mathrm{O}$ (294.35) (\%): C 69.37; H 6.16; N 19.03. Found: C 69.25; H 6.31; N 19.50.

$N$-[(5-nitrofuran-2-yl)methylidene]pyridine-3-carbohydrazide (13)

Yellow powder, yield: 94\%, M.p.: $238{ }^{\circ} \mathrm{C}$; IR: 3252, 3144 (N-H), 3018 (CH, arom.), 2969 (CH, aliph.), 1656 (C=O), 1557 (C=N), 1279, 1093 (C-OC), 1025 (N-N); ${ }^{1} \mathrm{H}$ NMR (600 MHz, DMSO- $\left.d_{6}\right) \delta$ (ppm): 7.32-7.33 (d, 1H, ArH, $\left.J=6 \mathrm{~Hz}\right), 7.60-7.62(\mathrm{~m}, 1 \mathrm{H}, \mathrm{ArH}), 7.82-7.83$ $(\mathrm{d}, 1 \mathrm{H}, \mathrm{ArH}, J=6 \mathrm{~Hz}), 8.27-8.28$ (d, 1H, ArH, $J=6 \mathrm{~Hz}), 8.40$ (s, 1H, =CH), 8.80-8.81 (d, $1 \mathrm{H}, \mathrm{ArH}, J=6 \mathrm{~Hz}), 9.08$ (s, 1H, ArH), 12.41 (s, 1H, NH); ${ }^{13} \mathrm{C}$ NMR (150 MHz, DMSO-d $\left.{ }_{6}\right)$ $\delta$ (ppm): 115.05, 116.23, 124.18, 129.11, 136.08 (5C ar ), 136.62 (=CH), 149.12, 151.92, 152.48, $153.14\left(4 \mathrm{C}_{\mathrm{ar}}\right), 162.52(\mathrm{C}=\mathrm{O})$; Anal. calc. for $\mathrm{C}_{11} \mathrm{H}_{8} \mathrm{~N}_{4} \mathrm{O}_{4}(260.21)(\%)$ : C 50.77; H 3.10; $\mathrm{N}$ 21.53. Found: C 50.35; H 3.51; N 21.64.

Representative ${ }^{1} \mathrm{H}$ NMR and ${ }^{13} \mathrm{C}$ NMR spectra of acylhydrazones of nicotinic acid (2-13) are shown in Supplementary Materials (Figures S1-S4).

\subsubsection{Synthesis of 3-Acetyl-2,5-disubstituted-1,3,4-oxadiazolines (14-25)}

The acetic anhydride $(10 \mathrm{~mL})$ was added to the acylhydrazones (2-13) (0.01 mole) obtained earlier. The cyclization reaction was carried out at reflux for $3 \mathrm{~h}$. After that, the acetic anhydride was distilled off under reduced pressure and crushed ice was added to the flask. The content of the flask was shaken variously until crystals precipitated, and left at room temperature for $24 \mathrm{~h}$. The precipitate formed was filtered off under reduced pressure and recrystallized from ethanol. The purity of the obtained compounds was checked by the TLC chromatography.

Detailed physicochemical properties of new derivatives of 3-acetyl-2,5-disubstituted1,3,4-oxadiazoline (14-25):

1-[2-(4-tert-butylphenyl)-5-(pyridin-3-yl)-1,3,4-oxadiazol-3(2H)-yl]ethan-1-one (14)

Creamy powder, yield: 67\%, M.p.: $84{ }^{\circ} \mathrm{C}$; IR: 3151 (CH, arom.), 2960 (CH, aliph.), 1675 (C=O), 1593 (C=N), 1283, 1015 (C-OC); ${ }^{1} \mathrm{H}$ NMR (600 MHz, DMSO-d 6 ) $\delta$ (ppm): 1.30 (s, $\left.9 \mathrm{H}, 3 \mathrm{xCH}_{3}\right), 2.28\left(\mathrm{~s}, 3 \mathrm{H}, \mathrm{CH}_{3}\right), 7.18\left(\mathrm{~s}, 1 \mathrm{H}, \mathrm{CH}_{\text {oxadiazole }}\right), 7.41-7.42(\mathrm{~d}, 1 \mathrm{H}, \mathrm{ArH}, \mathrm{J}=6 \mathrm{~Hz})$, 7.46-7.48 (d, 1H, ArH, $J=12 \mathrm{~Hz}), 7.51-7.53(\mathrm{~d}, 2 \mathrm{H}, \mathrm{ArH}, J=12 \mathrm{~Hz}), 7.67-7.68(\mathrm{~d}, 1 \mathrm{H}$, $\mathrm{ArH}, J=6 \mathrm{~Hz}), 7.87-7.89(\mathrm{~d}, 2 \mathrm{H}, \mathrm{ArH}, J=12 \mathrm{~Hz}), 8.09-8.10(\mathrm{~d}, 1 \mathrm{H}, \mathrm{ArH}, J=6 \mathrm{~Hz}) ;{ }^{13} \mathrm{C}$ NMR (150 MHz, DMSO-d $\left.d_{6}\right) \delta(\mathrm{ppm}): 21.69\left(\mathrm{CH}_{3}\right), 31.33\left(3 \times \mathrm{CH}_{3}\right), 35.24\left(\mathrm{C}_{t \text {-butyl }}\right), 92.64$ $\left(\mathrm{CH}_{\text {oxadiazole }}\right), 125.82,126.90,127.18,128.49,129.64,134.54,147.70\left(9 \mathrm{C}_{\text {ar }}\right), 156.26$ ( $\left.\mathrm{C}_{\text {oxadiazole }}\right)$, 164.92, $167.27\left(2 \mathrm{C}_{\mathrm{ar}}\right), 167.70(\mathrm{C}=\mathrm{O})$; Anal. calc. for $\mathrm{C}_{13} \mathrm{H}_{21} \mathrm{~N}_{3} \mathrm{O}_{2}(323.39)(\%): \mathrm{C} 70.57 ; \mathrm{H}$ $6.55 ; \mathrm{N} 12.99$. Found: C 70.88; H 6.56; N 12.88.

1-[2-(3-bromo-4-hydroxyphenyl)-5-(pyridin-3-yl)-1,3,4-oxadiazol-3(2H)-yl]ethan-1one (15)

Brown powder, yield: 75\%, M.p.: $68{ }^{\circ} \mathrm{C}$; IR: $3460(\mathrm{OH}), 3015(\mathrm{CH}$, arom. $), 2970(\mathrm{CH}$ aliph.), 1739 (C=O), $1556(\mathrm{C}=\mathrm{N}), 1217,1064$ (C-OC); ${ }^{1} \mathrm{H}$ NMR (600 MHz, DMSO-d 6 ) $\delta(\mathrm{ppm})$ : $2.42\left(\mathrm{~s}, 3 \mathrm{H}, \mathrm{CH}_{3}\right), 7.22\left(\mathrm{~s}, 1 \mathrm{H}, \mathrm{CH}_{\text {oxadiazole }}\right), 7.56-7.59(\mathrm{~m}, 2 \mathrm{H}, \mathrm{ArH}), 8.01-8.06(\mathrm{~m}, 1 \mathrm{H}, \mathrm{ArH})$, 8.20-8.22 (m, 1H, ArH), 8.26-8.33 (m, 1H, ArH), 8.77-8.78 (d, 1H, ArH, J = 6 Hz), 9.02 (s, $1 \mathrm{H}, \mathrm{ArH}), 7.95$ (s, 1H, OH); ${ }^{13} \mathrm{C}$ NMR (150 MHz, DMSO-d 6 ) $\delta(\mathrm{ppm}): 21.73\left(\mathrm{CH}_{3}\right), 90.69$ $\left(\mathrm{CH}_{\text {oxadiazole }}\right), 112.62,118.06,120.89,124.52,131.52,134.12,134.74,147.13,147.86,152.84$, $\left(10 \mathrm{C}_{\mathrm{ar}}\right), 153.37\left(\mathrm{C}_{\text {oxadiazole }}\right), 167.61\left(\mathrm{C}_{\mathrm{ar}}\right), 168.00(\mathrm{C}=\mathrm{O})$; Anal. calc. for $\mathrm{C}_{15} \mathrm{H}_{12} \mathrm{BrN}_{3} \mathrm{O}_{3}$ (362.18) (\%): C 49.74; H 3.34; N 11.60. Found: C 49.25; H 3.31; N 11.50.

1-[2-(3,5-dibromo-4-hydroxyphenyl)-5-(pyridin-3-yl)-1,3,4-oxadiazol-3(2H)-yl]ethan-1one (16) 
Creamy powder, yield: 84\%, M.p.: $116^{\circ} \mathrm{C}$; IR: $3456(\mathrm{OH}), 3016(\mathrm{CH}$, arom.), $2970(\mathrm{CH}$, aliph.), 1739 (C=O), $1570(\mathrm{C}=\mathrm{N}), 1217,1046$ (C-OC); ${ }^{1} \mathrm{H}$ NMR (600 MHz, DMSO- $\left.d_{6}\right) \delta$ (ppm): $2.34\left(\mathrm{~s}, 3 \mathrm{H}, \mathrm{CH}_{3}\right), 7.24\left(\mathrm{~s}, 1 \mathrm{H}, \mathrm{CH}_{\text {oxadiazole }}\right), 7.37-7.39(\mathrm{~d}, 1 \mathrm{H}, \mathrm{ArH}, J=12 \mathrm{~Hz}), 7.57-7.60$ (m, 2H, ArH), 7.90-7.91 (d, 1H, ArH, J = $6 \mathrm{~Hz}), 8.20-8.22$ (m, 1H, ArH), 8.77-8.78 (m, 1H, ArH), $9.02(\mathrm{~s}, 1 \mathrm{H}, \mathrm{OH}) ;{ }^{13} \mathrm{C}$ NMR $\left(150 \mathrm{MHz}, \mathrm{DMSO}-d_{6}\right) \delta(\mathrm{ppm}): 21.71\left(\mathrm{CH}_{3}\right), 91.30\left(\mathrm{CH}_{\text {oxadiazole }}\right)$, $116.42,120.89,124.56,125.23,127.95,132.05,134.69,136.46,147.79\left(9 \mathrm{C}_{\text {ar }}\right), 152.89$ ( $\left.\mathrm{C}_{\text {oxadiazole }}\right)$, 153.38, $167.72\left(2 \mathrm{C}_{\mathrm{ar}}\right), 168.71(\mathrm{C}=\mathrm{O})$; Anal. calc. for $\mathrm{C}_{15} \mathrm{H}_{11} \mathrm{BrN}_{3} \mathrm{O}_{3}$ (441.07) (\%): C 40.85; $\mathrm{H}$ $2.51 ;$ N 9.53. Found: C 40.27; H 2.31; N 9.80.

1-[2-(2-hydroxy-3,5-diiodophenyl)-5-(pyridin-3-yl)-1,3,4-oxadiazol-3(2H)-yl]ethan-1one (17)

Creamy powder, yield: 74\%, M.p.: $186{ }^{\circ} \mathrm{C}$; IR: $3456(\mathrm{OH}), 3016$ (CH, arom.), 2970 (CH aliph.), 1739 (C=O), 1588 (C=N), 1229, 1067 (C-OC); ${ }^{1} \mathrm{H}$ NMR (600 MHz, DMSO-d $\left.d_{6}\right)$ $\delta$ (ppm): $2.20\left(\mathrm{~s}, 3 \mathrm{H}, \mathrm{CH}_{3}\right), 7.16\left(\mathrm{~s}, 1 \mathrm{H}, \mathrm{CH}_{\text {oxadiazole }}\right), 7.52-7.61$ (m, 2H, ArH), 7.99-8.00 $(\mathrm{d}, 1 \mathrm{H}, \mathrm{ArH}, J=6 \mathrm{~Hz}), 8.16-8.17(\mathrm{~d}, 1 \mathrm{H}, \mathrm{ArH}, J=6 \mathrm{~Hz}), 8.34-8.35(\mathrm{~d}, 1 \mathrm{H}, \mathrm{ArH}, J=6 \mathrm{~Hz})$, 8.79-8.80 (m, 1H, ArH), 8.97 (s, 1H, OH); ${ }^{13} \mathrm{C}$ NMR (150 MHz, DMSO-d $\left.{ }_{6}\right) \delta(\mathrm{ppm}): 21.50$ $\left(\mathrm{CH}_{3}\right), 90.32\left(\mathrm{CH}_{\text {oxadiazole }}\right), 92.94,97.26,120.61,124.70,134.53,137.41,139.36,147.64,148.44$, $150.67\left(10 \mathrm{C}_{\mathrm{ar}}\right), 153.03$ ( $\left.\mathrm{C}_{\text {oxadiazole }}\right), 153.76\left(\mathrm{C}_{\mathrm{ar}}\right), 167.65(\mathrm{C}=\mathrm{O})$; Anal. calc. for $\mathrm{C}_{15} \mathrm{H}_{11} \mathrm{I}_{2} \mathrm{~N}_{3} \mathrm{O}_{3}$ (535.08) (\%): C 33.67; H 2.07; N 7.85. Found: C 32.89; H 2.15; N 7.50.

1-[2-(2-bromo-3-hydroxy-4-methoxyphenyl)-5-(pyridin-3-yl)-1,3,4-oxadiazol-3(2H)yl]ethan-1-one (18)

Yellow powder, yield: 64\%, M.p.: $124{ }^{\circ} \mathrm{C}$; IR: $3239(\mathrm{OH}), 3018(\mathrm{CH}$, arom.), $2887(\mathrm{CH}$ aliph.), 1667 (C=O), 1592 (C=N), 1286, 1015 (C-OC); ${ }^{1} \mathrm{H}$ NMR (600 MHz, DMSO-d 6 ) $\delta(p p m)$ : $2.38\left(\mathrm{~s}, 3 \mathrm{H}, \mathrm{CH}_{3}\right), 3.94\left(\mathrm{~s}, 3 \mathrm{H}, \mathrm{OCH}_{3}\right), 7.11\left(\mathrm{~s}, 1 \mathrm{H}, \mathrm{CH}_{\text {oxadiazole }}\right), 7.15-7.17$ (d, 2H, ArH, $J=12 \mathrm{~Hz}), 7.37-7.38(\mathrm{~d}, 1 \mathrm{H}, \mathrm{ArH}, J=6 \mathrm{~Hz}), 7.41-7.43(\mathrm{~d}, 2 \mathrm{H}, \mathrm{ArH}, J=12 \mathrm{~Hz}), 7.83-7.85$ $(\mathrm{d}, 1 \mathrm{H}, \mathrm{ArH}, J=12 \mathrm{~Hz}), 10.12(\mathrm{~s}, 1 \mathrm{H}, \mathrm{OH}) ;{ }^{13} \mathrm{C} \mathrm{NMR}\left(150 \mathrm{MHz}, \mathrm{DMSO}-d_{6}\right) \delta$ (ppm): 21.89 $\left(\mathrm{CH}_{3}\right), 56.94\left(\mathrm{OCH}_{3}\right), 100.52\left(\mathrm{CH}_{\text {oxadiazole }}\right), 110.92,113.84,120.60,122.47,127.13,128.28$, 135.71, 144.52, 149.04, $151.34\left(10 \mathrm{C}_{\mathrm{ar}}\right), 153.83$ ( $\left.\mathrm{C}_{\text {oxadiazole }}\right), 156.78\left(\mathrm{C}_{\mathrm{ar}}\right), 165.14(\mathrm{C}=\mathrm{O})$; Anal. calc. for $\mathrm{C}_{16} \mathrm{H}_{14} \mathrm{BrN}_{3} \mathrm{O}_{4}$ (392.20) (\%): C 49.00; H 3.60; N 10.71. Found: C 49.25; H 3.20; N 10.50.

1-[2-(2-bromo-5-fluorophenyl)-5-(pyridin-3-yl)-1,3,4-oxadiazol-3(2H)-yl]ethan-1-one (19)

White powder, yield: 74\%, M.p.: $118{ }^{\circ} \mathrm{C}$; IR: 3016 (CH, arom.), 2970 (CH aliph.), 1739 (C=O), 1588 (C=N), 1217, 1031 (C-OC) ; ${ }^{1} \mathrm{H}$ NMR (600 MHz, DMSO-d 6 ) $\delta$ (ppm): 2.32 (s, 1H, $\left.\mathrm{CH}_{3}\right), 7.29$ (s, 1H, $\left.\mathrm{CH}_{\text {oxadiazole }}\right), 7.32-7.35(\mathrm{~m}, 1 \mathrm{H}, \mathrm{ArH}), 7.39-7.41(\mathrm{~m}, 1 \mathrm{H}, \mathrm{ArH}), 7.56-7.58$ (m, 1H, ArH), 7.79-7.82 (m, 1H, ArH), 8.16-8.18 (m, 1H, ArH), 8.76-8.77 (d, 1H, ArH, $J=6 \mathrm{~Hz}), 8.98(\mathrm{~s}, 1 \mathrm{H}, \mathrm{ArH}) ;{ }^{13} \mathrm{C} \mathrm{NMR}\left(150 \mathrm{MHz}, \mathrm{DMSO}-d_{6}\right) \delta(\mathrm{ppm}): 21.66\left(\mathrm{CH}_{3}\right), 92.21$ $\left(\mathrm{CH}_{\text {oxadiazole }}\right), 117.22,119.79,120.87,124.58,134.62,135.85,136.79,147.70\left(8 \mathrm{C}_{\mathrm{ar}}\right), 152.87$ $\left(\mathrm{C}_{\text {oxadiazole }}\right), 153.07,161.25,162.88\left(3 \mathrm{C}_{\mathrm{ar}}\right), 167.82(\mathrm{C}=\mathrm{O})$; Anal. calc. for $\mathrm{C}_{15} \mathrm{H}_{11} \mathrm{BrFN}_{4} \mathrm{O}_{2}$ (364.17) (\%): C 49.47; H 3.04; N 11.52. Found: C 49.88; H 3.08; N 11.99.

1-[2-(4-bromo-2-fluorophenyl)-5-(pyridin-3-yl)-1,3,4-oxadiazol-3(2H)-yl]ethan-1-one (20)

White powder, yield: 68\%, M.p.: $100{ }^{\circ} \mathrm{C}$; IR: 3016 (CH, arom.), 2970 (CH aliph.), 1683 (C=O), 1592 (C=N), 1212, 1042 (C-OC); ${ }^{1} \mathrm{H}$ NMR (600 MHz, DMSO-d 6 ) $\delta$ (ppm): 2.27 (s, 3H, $\left.\mathrm{CH}_{3}\right), 7.32\left(\mathrm{~s}, 1 \mathrm{H}, \mathrm{CH}_{\text {oxadiazole }}\right), 7.53-7.56(\mathrm{~m}, 2 \mathrm{H}, \mathrm{ArH}), 7.57-7.59$ (m, 2H, ArH), 7.68-7.70 (d, 1H, ArH, $J=12 \mathrm{~Hz}), 8.18-8.20$ (m, 1H, ArH), 8.77-8.78 (m, 1H, ArH), 8.99 (s, 1H, ArH); ${ }^{13} \mathrm{C}$ NMR (150 MHz, DMSO-d 6$) \delta(\mathrm{ppm}): 21.56\left(\mathrm{CH}_{3}\right), 88.72\left(\mathrm{CH}_{\text {oxadiazole }}\right), 120.05,120.82$, $123.10,124.61,128.56,131.67,134.57,147.65\left(8 \mathrm{C}_{\mathrm{ar}}\right), 152.92\left(\mathrm{C}_{\text {oxadiazole }}\right), 153.28,159.78,161.46$ $\left(3 \mathrm{C}_{\mathrm{ar}}\right), 167.34(\mathrm{C}=\mathrm{O})$; Anal. calc. for $\mathrm{C}_{15} \mathrm{H}_{11} \mathrm{BrFN}_{3} \mathrm{O}_{2}$ (364.17) (\%): C 49.47; H 3.04; $\mathrm{N} 11.52$. Found: C 49.25; H 3.02; N 11.50.

1-[2-(2-chloro-6-fluorophenyl)-5-(pyridin-3-yl)-1,3,4-oxadiazol-3(2H)-yl]ethan-1-one (21)

Creamy powder, yield: 71\%, M.p.: $102{ }^{\circ} \mathrm{C}$; IR: 3049 (CH, arom.), 2970 (CH aliph.), 1655 $(\mathrm{C}=\mathrm{O}), 1577$ (C=N), 1210, 1030 (C-OC); ${ }^{1} \mathrm{H}$ NMR (600 MHz, DMSO-d 6 ) $\delta$ (ppm): $2.23(\mathrm{~s}, 3 \mathrm{H}$, $\left.\mathrm{CH}_{3}\right), 7.32-7.35(\mathrm{~m}, 1 \mathrm{H}, \mathrm{ArH}), 7.43-7.44(\mathrm{~d}, 1 \mathrm{H}, \mathrm{ArH}, J=6 \mathrm{~Hz}), 7.54-7.58(\mathrm{~m}, 2 \mathrm{H}, \mathrm{ArH})$, 7.57 (s, 1H, $\left.\mathrm{CH}_{\text {oxadiazole }}\right), 8.20-8.22$ (m, 1H, ArH), 8.77-8.78 (m, 1H, ArH), 9.01 (s, 1H, ArH); ${ }^{13} \mathrm{C}$ NMR (150 MHz, DMSO- $\left.d_{6}\right) \delta(\mathrm{ppm}): 21.44\left(\mathrm{CH}_{3}\right), 87.26\left(\mathrm{CH}_{\text {oxadiazole }}\right), 116.03,120.83$, $121.25,124.62,126.95,133.39,134.52,147.61$ ( $\left.8 C_{\text {ar }}\right), 152.88$ ( $\left.C_{\text {oxadiazole }}\right), 153.10,161.23,162.91$ 
$\left(3 \mathrm{C}_{\mathrm{ar}}\right), 167.09(\mathrm{C}=\mathrm{O})$; Anal. calc. for $\mathrm{C}_{15} \mathrm{H}_{11} \mathrm{ClFN}_{3} \mathrm{O}_{2}$ (319.72) (\%): C 56.35; H 3.47; N 13.14. Found: C 55.99; H 3.62; N 13.49 .

1-[2-(2-chloro-5-nitrophenyl)-5-(pyridin-3-yl)-1,3,4-oxadiazol-3(2H)-yl]ethan-1-one (22)

Grey powder, yield: 88\%, M.p.: $168^{\circ} \mathrm{C}$; IR: 3016 (CH, arom.), 2970 (CH aliph.), 1676 $(\mathrm{C}=\mathrm{O}), 1518(\mathrm{C}=\mathrm{N}), 1215,1020(\mathrm{C}-\mathrm{OC}){ }^{1}{ }^{1} \mathrm{H}$ NMR $\left(600 \mathrm{MHz}, \mathrm{DMSO}-d_{6}\right) \delta(\mathrm{ppm}): 2.32(\mathrm{~s}, 3 \mathrm{H}$, $\left.\mathrm{CH}_{3}\right), 7.49\left(\mathrm{~s}, 1 \mathrm{H}, \mathrm{CH}_{\text {oxadiazole }}\right), 7.57-7.59(\mathrm{~m}, 1 \mathrm{H}, \mathrm{ArH}), 7.90-7.92(\mathrm{~d}, 1 \mathrm{H}, \mathrm{ArH}, J=12 \mathrm{~Hz})$, 8.19-8.21 (m, 1H, ArH), 8.32-8.36 (m, 2H, ArH), 8.78-8.79 (d, 1H, ArH, J = $6 \mathrm{~Hz}), 9.00$ (s, $1 \mathrm{H}, \mathrm{ArH}) ;{ }^{13} \mathrm{C}$ NMR $\left(150 \mathrm{MHz}, \mathrm{DMSO}-d_{6}\right) \delta(\mathrm{ppm}): 21.57\left(\mathrm{CH}_{3}\right), 90.54\left(\mathrm{CH}_{\text {oxadiazole }}\right)$, $120.69,124.62,125.31,126.97,132.55,134.68,139.42,147.16,147.74,150.26\left(10 \mathrm{C}_{\text {ar }}\right), 153.00$ $\left(\mathrm{C}_{\text {oxadiazole }}\right), 153.35\left(\mathrm{C}_{\mathrm{ar}}\right), 167.98(\mathrm{C}=\mathrm{O})$; Anal. calc. for $\mathrm{C}_{15} \mathrm{H}_{11} \mathrm{ClN}_{4} \mathrm{O}_{4}$ (346.72) (\%): C 51.96; H 3.20; N 16.16. Found: C 49.85; H 3.21; N 17.03.

1-[2-(2,3-difluorophenyl)-5-(pyridin-3-yl)-1,3,4-oxadiazol-3(2H)-yl]ethan-1-one (23)

Brown powder, yield: 63\%, M.p.: $88^{\circ} \mathrm{C}$; IR: 3035 (CH, arom.), 2970 (CH aliph.), 1666 $(\mathrm{C}=\mathrm{O}), 1591(\mathrm{C}=\mathrm{N}), 1210,1019(\mathrm{C}-\mathrm{OC}) ;{ }^{1} \mathrm{H}$ NMR $\left(600 \mathrm{MHz}, \mathrm{DMSO}-d_{6}\right) \delta(\mathrm{ppm}): 2.28(\mathrm{~s}, 3 \mathrm{H}$, $\left.\mathrm{CH}_{3}\right), 7.30-7.33(\mathrm{~m}, 1 \mathrm{H}, \mathrm{ArH}), 7.38\left(\mathrm{~s}, 1 \mathrm{H}, \mathrm{CH}_{\text {oxadiazole }}\right), 7.40-7.41(\mathrm{~m}, 1 \mathrm{H}, \mathrm{ArH}), 7.57-7.59$ $(\mathrm{m}, 2 \mathrm{H}, \mathrm{ArH}), 8.20-8.21(\mathrm{~m}, 1 \mathrm{H}, \mathrm{ArH}), 8.78-8.79(\mathrm{~m}, 1 \mathrm{H}, \mathrm{ArH}), 9.01(\mathrm{~s}, 1 \mathrm{H}, \mathrm{ArH}) ;{ }^{13} \mathrm{C} \mathrm{NMR}$ $\left(150 \mathrm{MHz}, \mathrm{DMSO}-d_{6}\right) \delta(\mathrm{ppm}): 21.57\left(\mathrm{CH}_{3}\right), 88.52\left(\mathrm{CH}_{\text {oxadiazole }}\right), 119.82,119.93,120.77$, $124.62,125.12,125.85,126.01,126.06,134.61,147.68\left(10 \mathrm{C}_{\mathrm{ar}}\right), 152.95\left(\mathrm{C}_{\text {oxadiazole }}\right), 153.28\left(\mathrm{C}_{\mathrm{ar}}\right)$, $167.42(\mathrm{C}=\mathrm{O})$; Anal. calc. for $\mathrm{C}_{15} \mathrm{H}_{11} \mathrm{~F}_{2} \mathrm{~N}_{3} \mathrm{O}_{2}$ (303.26) (\%): C 59.41; $\mathrm{H} 3.66 ; \mathrm{N}$ 13.86. Found: C $59.25 ; \mathrm{H} 3.31 ; \mathrm{N} 13.42$.

1-[5-(pyridin-3-yl)-2-[4-(pyrrolidin-1-yl)phenyl]-1,3,4-oxadiazol-3(2H)-yl]ethan-1one (24)

Brown powder, yield: 72\%, M.p.: $62{ }^{\circ} \mathrm{C}$; IR: 3025 (CH, arom.), 2970 (CH aliph.), 1652 $(\mathrm{C}=\mathrm{O}), 1593(\mathrm{C}=\mathrm{N}), 1217,1118(\mathrm{C}-\mathrm{OC}) ;{ }^{1} \mathrm{H}$ NMR $\left(600 \mathrm{MHz}, \mathrm{DMSO}-d_{6}\right) \delta(\mathrm{ppm}): 2.13(\mathrm{~s}$, $\left.3 \mathrm{H}, \mathrm{CH}_{3}\right), 2.39-2.40\left(\mathrm{~m}, 4 \mathrm{H}, 2 \times \mathrm{CH}_{2-\text { pyrrolidine }}\right), 2.61-2.63\left(\mathrm{~m}, 4 \mathrm{H}, 2 \mathrm{xCH}_{2}\right.$-pyrrolidine $), 7.30-7.33$ $(\mathrm{m}, 2 \mathrm{H}, \mathrm{ArH}), 7.38\left(\mathrm{~s}, 1 \mathrm{H}, \mathrm{CH}_{\text {oxadiazole }}\right), 7.40-7.41(\mathrm{~m}, 1 \mathrm{H}, \mathrm{ArH}), 7.55-7.59(\mathrm{~m}, 2 \mathrm{H}, \mathrm{ArH})$, 8.20-8.21 (m, 1H, ArH), 8.78-8.79 (m, 1H, ArH), 9.01 (s, 1H, ArH); ${ }^{13} \mathrm{C}$ NMR (150 MHz, DMSO- $\left.d_{6}\right) \delta$ (ppm): $21.52\left(\mathrm{CH}_{3}\right), 25.38\left(2 \mathrm{xCH}_{2 \text {-pyrrolidine }}\right), 47.84\left(2 \mathrm{xCH}_{2}\right.$-pyrrolidine $), 101.3$ $\left(\mathrm{CH}_{\text {oxadiazole }}\right), 107.20,111.75,124.09,124.72,128.28,132.16,135.71,148.25\left(10 \mathrm{C}_{\text {ar }}\right), 152.15$ $\left(\mathrm{C}_{\text {oxadiazole }}\right), 158.12\left(\mathrm{C}_{\mathrm{ar}}\right), 166.20(\mathrm{C}=\mathrm{O})$; Anal. calc. for $\mathrm{C}_{19} \mathrm{H}_{20} \mathrm{~N}_{4} \mathrm{O}_{2}(336.39)(\%)$ : $\mathrm{C} 67.84 ; \mathrm{H}$ 5.99; N 16.66. Found: C 68.02; H 6.14; N 16.54.

1-[2-(5-nitrofuran-2-yl)-5-(pyridin-3-yl)-1,3,4-oxadiazol-3(2H)-yl]ethan-1-one (25)

Brown powder, yield: 87\%, M.p.: $108{ }^{\circ} \mathrm{C}$; IR: 3016 (CH, arom.), 2970 (CH aliph.), 1739 $(\mathrm{C}=\mathrm{O}), 1541(\mathrm{C}=\mathrm{N}), 1217,1016(\mathrm{C}-\mathrm{OC}) ;{ }^{1} \mathrm{H}$ NMR $\left(600 \mathrm{MHz}, \mathrm{DMSO}-d_{6}\right) \delta(\mathrm{ppm}): 2.31(\mathrm{~s}$, $\left.3 \mathrm{H}, \mathrm{CH}_{3}\right), 7.27-7.28(\mathrm{~d}, 1 \mathrm{H}, \mathrm{ArH}, J=6 \mathrm{~Hz}), 7.41\left(\mathrm{~s}, 1 \mathrm{H}, \mathrm{CH}_{\text {oxadiazole }}\right), 7.59-7.61(\mathrm{~m}, 1 \mathrm{H}$, $\mathrm{ArH}), 7.73-7.74(\mathrm{~d}, 1 \mathrm{H}, \mathrm{ArH}, J=6 \mathrm{~Hz}), 8.21-8.23(\mathrm{~m}, 1 \mathrm{H}, \mathrm{ArH}), 8.79-8.80(\mathrm{~m}, 1 \mathrm{H}, \mathrm{ArH})$, 9.01-9.02 (d, $1 \mathrm{H}, \mathrm{ArH}, J=6 \mathrm{~Hz}) ;{ }^{13} \mathrm{C} \mathrm{NMR}\left(150 \mathrm{MHz}, \mathrm{DMSO}-d_{6}\right) \delta(\mathrm{ppm}): 21.60\left(\mathrm{CH}_{3}\right), 85.14$ $\left(\mathrm{CH}_{\text {oxadiazole }}\right), 113.67,115.18,120.48,124.67,134.70,147.74,150.74,152.28\left(8 \mathrm{C}_{\mathrm{ar}}\right), 153.14$ $\left(\mathrm{C}_{\text {oxadiazole }}\right), 154.31\left(\mathrm{C}_{\mathrm{ar}}\right), 167.84(\mathrm{C}=\mathrm{O})$; Anal. calc. for $\mathrm{C}_{13} \mathrm{H}_{10} \mathrm{~N}_{4} \mathrm{O}_{5}(302.24)(\%)$ : $\mathrm{C} 51.66 ; \mathrm{H}$ 3.33; N 18.54. Found: C 49.25; H 3.51; N 18.50.

Representative ${ }^{1} \mathrm{H}$ NMR and ${ }^{13} \mathrm{C}$ NMR spectra of 3-acetyl-2,5-disubstituted-1,3,4oxadiazoline (14-25) are shown in Supplementary Materials (Figures S5-S8).

\subsection{Microbiology}

All of the obtained compounds were tested for their antimicrobial activity by the broth microdilution method according to the procedures described earlier by our research group [58-62]. All tests were in the line with the European Committee on Antimicrobial Susceptibility Testing (EUCAST) [63] and Clinical and Laboratory Standards Institute [64] recommendations. In the assays, we used a panel of reference and clinical or saprophytic strains of microorganisms from the American Type Culture Collection (ATCC) in microbiology assays. All of the experiments were repeated three times, and representative data are presented. Stock solutions were prepared by dissolving synthesized substances in DMSO. 


\subsection{Cytotoxicity Studies}

\subsubsection{Cell Cultures}

Human colon adenocarcinoma cell line HT29 (ATCC No. HTB-38), derived from a grade I tumour, was cultured in RPMI 1640 medium supplemented with $10 \%$ fetal calf serum (FCS) (GibcoTM, Paisley, UK) and antibiotics (100 U/mL penicillin and $100 \mu \mathrm{g} / \mathrm{mL}$ streptomycin) (Sigma, St. Louis, MO, USA) at $37{ }^{\circ} \mathrm{C}$ in a humidified atmosphere with $5 \%$ $\mathrm{CO}_{2}$. Human normal colon epithelial cells CCD 841 CoTr (ATCC No. CRL-1807) were cultured in RPMI 1640 + DMEM (1:1) medium (Sigma, St. Louis, MO, USA) supplemented with $10 \% \mathrm{FCS}$ and antibiotics at $34{ }^{\circ} \mathrm{C}$ in a $5 \% \mathrm{CO}_{2} / 95 \%$ air atmosphere.

\subsubsection{MTT Assay}

After $24 \mathrm{~h}$ incubation of cells with the tested compounds in $100 \mu \mathrm{L}$ of culture medium, MTT solution $(5 \mathrm{mg} / \mathrm{mL}, 25 \mu \mathrm{L} /$ well) was added and incubated for an additional $3 \mathrm{~h}$. The purple crystals of formazan which formed in the medium were solubilized overnight in $10 \%$ sodium dodecyl sulphate (SDS) in a $0.01 \mathrm{M} \mathrm{HCl}$ mixture. The product was quantified spectrophotometrically by measuring its absorbance at $570 \mathrm{~nm}$ with the use of an Emax Microplate Reader (Molecular Devices Corporation, Menlo Park, CA).

\subsubsection{Neutral Red (NR) Uptake Assay}

Cells were grown for $24 \mathrm{~h}$ in a 96-well multiplate in $100 \mu \mathrm{L}$ of culture medium (RPMI 1640) supplemented with $5 \%$ fetal bovine serum (FBS) and tested compounds. Subsequently, the medium was discarded and a $0.4 \%$ neutral red solution in $2 \%$ FBS medium was added to each well. The plate was incubated for $3 \mathrm{~h}$ at $37{ }^{\circ} \mathrm{C}$ in a humidified $5 \% \mathrm{CO}_{2} / 95 \%$ air incubator. After incubation, the dye-containing medium was removed, the cells were fixed with $1 \% \mathrm{CaCl}_{2}$ in $4 \%$ paraformaldehyde, and the incorporated dye was solubilized using $1 \%$ acetic acetate in a $50 \%$ ethanol solution $(100 \mu \mathrm{L})$. The plates were gently shaken for $20 \mathrm{~min}$ at room temperature and the absorbance of the extracted dye was measured spectrophotometrically at $540 \mathrm{~nm}$.

\subsubsection{Nitric Oxide (NO) Measurement}

Nitrate, i.e., a stable end product of $\mathrm{NO}$, was determined in culture supernatants with a spectrophotometric method based on the Griess reaction. Culture supernatants were collected from cell cultures treated with specific concentrations of the tested compounds. Briefly, $100 \mu \mathrm{L}$ of the culture supernatant was placed in 96-well flat-bottomed plates in triplicate and incubated with $100 \mu \mathrm{L}$ of Griess reagent (1\% sulfanilamide/0.1\% N-(1naphthyl)ethylenediamine dihydrochloride) in $3 \% \mathrm{H}_{3} \mathrm{PO}_{4}$ at room temperature for $10 \mathrm{~min}$. The optical density was measured at $550 \mathrm{~nm}$ using a microplate reader. A standard curve was prepared with the use of $0.5-25 \mu \mathrm{M}$ sodium nitrite $\left(\mathrm{NaNO}_{2}\right)$ for calibration.

\subsubsection{DPPH Free Radical Scavenging Test}

Free radical scavenging activity of terpene was measured by the DPPH assay. Briefly, $100 \mu \mathrm{L}$ of DPPH solution $(0.2 \mathrm{mg} / \mathrm{mL}$ in ethanol) was added to $100 \mu \mathrm{L}$ of the tested compound concentrations $(0-200 \mu \mathrm{g} / \mathrm{mL})$. Trolox in increasing concentrations $(1-50 \mu \mathrm{g} / \mathrm{mL})$ was used as a standard. After $20 \mathrm{~min}$ of incubation at room temperature, the absorbances of the solutions were measured at $515 \mathrm{~nm}$. The lower the absorbance, the higher the free radical scavenging activity of the compounds. The activity of each compound was determined by comparing its absorbance with that of the standard.

The ability of the compounds to scavenge the DPPH radical was calculated by the following formula:

$$
\text { DPPH scavenging effect }(\%)=[(\text { Xcontrol }- \text { Xcompound } / \text { Xcontrol }) \times 100]
$$

Xcontrol is the absorbance of the control and Xcompound is the absorbance in the presence of synthesized compounds. 


\subsubsection{Ferric-Reducing Antioxidant Power Assay}

Each compound concentration was dissolved in Milli-Q water and mixed with an equal volume of $0.2 \mathrm{M}$ sodium phosphate buffer ( $\mathrm{pH}$ 6.6) and $1 \%$ potassium ferricyanide. The mixture was incubated for $30 \mathrm{~min}$ at $37^{\circ} \mathrm{C}$. Thereafter, $10 \%$ trichloroacetic acid $(w / v)$ was added and the mixture was centrifuged at $1000 \times g$ for $5 \mathrm{~min}$. One millilitre of the upper layer was mixed with an equal volume of Milli- $Q$ water and $0.1 \%$ ferric chloride. The absorbance was read at $700 \mathrm{~nm}$ with the use of an EL800 Universal Microplate Reader (BioTek Instruments, Winooski, VT, USA). Ascorbic acid $(0-150 \mu \mathrm{g} / \mathrm{mL})$ was used as a positive control.

\subsubsection{May-Grünwald-Giemsa (MGG) Staining}

The cells were incubated in 24-well plates in $1 \mathrm{~mL}$ of culture medium supplemented with tested compounds. After $24 \mathrm{~h}$ of incubation $\left(37^{\circ} \mathrm{C}\right.$ in a humidified $5 \% \mathrm{CO}_{2} / 95 \%$ air), the medium was discarded and the cell cultures were rinsed with RPMI 1640 medium and stained with May-Grünwald (MG) stain for 5 min followed by staining for another $5 \mathrm{~min}$ in MG diluted in an equal quantity of water. The MG was removed and Giemsa reagent (diluted 1:20 in water) was added to the cells, which were next incubated at room temperature for $15 \mathrm{~min}$. After that, the cells were rinsed three times with water, dried and subjected to microscopic observations (Olympus, BX51; Olympus).

\subsubsection{Statistical Analysis}

Results are presented as mean \pm SD from three experiments. Data were analysed with the use of one-way ANOVA with Dunnett's post hoc test. Differences of $p \leq 0.05$ were considered as significant.

\subsection{Molecular Docking}

A molecular docking study was carried out using the Autodock Vina 4.2.

The X-ray crystal structures of target proteins were downloaded from the Protein Data Bank. The AutoDock tools were used to remove water molecules, add polar hydrogen atoms, merge nonpolar hydrogen atoms, define rotatable bonds, and add Kollman charges. The validations of selected docking parameters were performed by redocking of the initial ligands from the used enzyme structures.

The structure of nitrofurantoin was downloaded from the PubChem portal. The 3D structures of the synthesized compounds were prepared with the use of HyperChem 7.5 software. At first, the molecules were optimized by the method of molecular mechanics $\mathrm{MM}+$ with the achievement of an RMS gradient of less than $0.1 \mathrm{kcal} /(\mathrm{mol} \AA)$. The final minimization of the energies of the investigated intermediates was carried out by the semi-empirical quantum chemical method PM3 until the RMS gradient was less than 0.01 $\mathrm{kcal} /(\mathrm{mol} \AA)$. The visualization and interpretation of the obtained data were performed with the use of Discovery Studio Visualizer.

Theoretical predictions of AMDET profiles were performed using SwissADME (http: / /www.swissadme.ch/) (accessed on 21 February 2022) and ProTOX (https:/ / tox-new. charite.de/protox_II/) portals (accessed on 21 February 2022).

\section{Conclusions}

In summary, in this paper, we presented the synthesis, results of antimicrobial activity and cytotoxicity assays and molecular docking study of twenty-four new nicotinic acid derivatives. The presented synthesis was carried out in two stages. In the first stage, as a result of the condensation reaction, we obtained twelve acylhydrazones (2-13), which were subjected to cyclization reaction in acetic anhydride to obtain twelve new 3-acetyl-2,5disubstituted-1,3,4-oxadiazoline derivatives (14-25). All of the obtained substances were subjected to a series of in vitro antimicrobial activity assays which showed that twelve of the synthesized compounds had antimicrobial activity against the tested strains. Importantly, four of the obtained compounds showed activity towards the resistant MRSA strain (Staphy- 
lococcus aureus ATCC 43300) within the range of MIC $=7.81-31.25 \mu \mathrm{g} / \mathrm{mL}$. Additionally, on the basis of the presented data, it can be concluded that acylhydrazones showed better antibacterial activity in relation to the corresponding 3-acetyl-1,3,4-oxadiazoline derivatives. The most active of the tested compounds, i.e., compound $\mathbf{1 3}$ with the 5-nitrofuran substituent, showed the highest activity against Staphylococcus epidermidis ATCC 12228 $(\mathrm{MIC}=1.95 \mu \mathrm{g} / \mathrm{mL})$, S. aureus ATCC $6538(\mathrm{MIC}=3.91 \mu \mathrm{g} / \mathrm{mL})$ as well as high activity against the MRSA S. aureus ATCC 43300 strain $(\mathrm{MIC}=7.81 \mu \mathrm{g} / \mathrm{mL})$. Selected substances have also undergone cytotoxicity tests which showed that they are safe for normal cell lines. Additionally, molecular docking tests confirmed the obtained results.

Supplementary Materials: The following supporting information can be downloaded at: https: //www.mdpi.com/article/10.3390/ijms23052823/s1.

Author Contributions: Conceptualization, K.P. and Ł.P.; methodology, K.P., A.B., D.K., R.P. and Ł.P.; formal analysis, K.P., A.B., D.K., M.W. and Ł.P.; investigation, K.P., A.B., D.K., R.P. and Ł.P.; writing—original draft preparation, K.P., A.B., D.K., R.P. and Ł.P.; writing—review and editing, K.P. and Ł.P.; visualization, K.P., D.K., R.P. and Ł.P.; supervision, K.P., M.W. and Ł.P. All authors have read and agreed to the published version of the manuscript.

Funding: This research received no external funding.

Institutional Review Board Statement: Not applicable.

Informed Consent Statement: Not applicable.

Data Availability Statement: Data are contained within the article.

Conflicts of Interest: The authors declare no conflict of interest.

\section{References}

1. Laxminarayan, R.; Duse, A.; Wattal, C.; Zaidi, A.K.M.; Wertheim, H.F.L.; Sumpradit, N.; Vlieghe, E.; Hara, G.L.; Gould, I.M.; Goossens, H.; et al. Antibiotic resistance-the need for global solutions. Lancet Infect. Dis. 2013, 13, 1057-1098. [CrossRef]

2. Yadav, S.; Kapley, A. Antibiotic resistance: Global health crisis and metagenomics. Biotechnol. Rep. 2021, 29, e00604. [CrossRef] [PubMed]

3. Zhang, Y.; Kashikar, A.; Brown, C.A.; Denys, G.; Bush, K. Unusual Escherichia coli PBP 3 insertion sequence identified from a collection of carbapenem-resistant Enterobacteriaceae tested in vitro with a combination of ceftazidime-, ceftaroline-, or aztreonam-avibactam. Antimicrob. Agents Chemother. 2017, 61, e00389-17. [CrossRef] [PubMed]

4. Maillard, J.Y.; Bloomfield, S.F.; Courvalin, P.; Essack, S.Y.; Gandra, S.; Gerba, C.P.; Rubino, J.R.; Scott, E.A. Reducing antibiotic prescribing and addressing the global problem of antibiotic resistance by targeted hygiene in the home and everyday life settings: A position paper. Am. J. Infect. Control 2020, 48, 1090-1099. [CrossRef]

5. Christopher, K.C.; Rita, W.Y.; Leung, S.S.; Mamie, H.U.I.; Ip, M. Overcoming the rising incidence and evolving mechanisms of antibiotic resistance by novel drug delivery approaches-An overview. Adv. Drug Deliv. Rev. 2021, 181, 114078. [CrossRef]

6. Edwards, F.; MacGowan, A.; Macnaughton, E. Antibiotic resistance. Medicine 2021, 49, 632-637. [CrossRef]

7. Ventola, C.L. The Antibiotics Resistance Crisis. Pharm. Ther. 2015, 40, 277-283. [CrossRef]

8. Faruki, H.; Sparling, P.F. Genetics of resistance in a non- $\beta$-lactamase-producing gonococcus with relatively high-level penicillin resistance. Antimicrob. Agents Chemother. 1986, 30, 856-860. [CrossRef] [PubMed]

9. Adler, M.; Anjum, M.; Andersson, D.I.; Sandegren, L. Influence of acquired $\beta$-lactamases on the evolution of spontaneous carbapenem resistance in Escherichia coli. J. Antimicrob. Chemother. 2013, 68, 51-59. [CrossRef] [PubMed]

10. Wang, Y.; Liao, J.; Mehmood, K.; Chang, Y.F.; Tang, Z.; Zhang, H. Escherichia coli isolated in pigs, Guangdong, China: Emergence of extreme drug resistance (XDR) bacteria. J. Infect. 2020, 81, 318-356. [CrossRef]

11. Diallo, O.O.; Baron, S.A.; Abat, C.; Colson, P.; Chaudet, H.; Rolain, J.-M. Antibiotic Resistance Surveillance Systems: A Review. J. Glob. Antimicrob. Resist. 2020, 23, 430-438. [CrossRef] [PubMed]

12. Singh, A.; Turner, J.M.; Tomberg, J.; Fedarovich, A.; Unemo, M.; Nicholas, R.A.; Davies, C. Mutations in penicillin-binding protein 2 from cephalosporin-resistant Neisseria gonorrhoeae hinder ceftriaxone acylation by restricting protein dynamics. J. Biol. Chem. 2020, 295, 7529-7543. [CrossRef] [PubMed]

13. Chen, Z.; Han, C.; Huang, X.; Liu, Y.; Guo, D.; Ye, X. A molecular epidemiological study of methicillin-resistant and methicillinsusceptible staphylococcus aureus contamination in the airport environment. Infect. Drug Resist. 2018, 11, 2363-2375. [CrossRef]

14. García-Fernández, E.; Koch, G.; Wagner, R.M.; Fekete, A.; Stengel, S.T.; Schneider, J.; Mielich-Süss, B.; Geibel, S.; Markert, S.M.; Stigloher, C.; et al. Membrane Microdomain Disassembly Inhibits MRSA Antibiotic Resistance. Cell 2017, 171, 1354-1367.e20. [CrossRef] 
15. Fesatidou, M.; Petrou, A.; Athina, G. Heterocycle Compounds with Antimicrobial Activity. Curr. Pharm. Des. 2020, 26, 867-904. [CrossRef] [PubMed]

16. Son, N.T.; Huong, V.T.T.; Lien, V.T.K.; Nga, D.T.Q.; Hai Au, T.T.; Nga, T.T.; Minh Hoa, L.N.; Binh, T.Q. First Report on MultidrugResistant Methicillin-Resistant Staphylococcus aureus Isolates in Children Admitted to Tertiary Hospitals in Vietnam S. J. Microbiol. Biotechnol. 2019, 29, 1460-1469. [CrossRef]

17. Sikora, A.; Zahra, F. Nosocomial Infections. In StatPearls [Internet]; StatPearls Publishing: Treasure Island, FL, USA, 2022. Available online: https:/ / www.ncbi.nlm.nih.gov/books/NBK559312/ (accessed on 18 February 2022).

18. Yang, X.; Guo, R.; Xie, B.; Lai, Q.; Xu, J.; Hu, N.; Wan, L.; Dai, M.; Zhang, B. Drug resistance of pathogens causing nosocomial infection in orthopedics from 2012 to 2017: A 6-year retrospective study. J. Orthop. Surg. Res. 2021, 16, 100. [CrossRef]

19. Khan, H.A.; Baig, F.K.; Mehboob, R. Nosocomial infections: Epidemiology, prevention, control and surveillance. Asian Pac. J. Trop. Biomed. 2017, 7, 478-482. [CrossRef]

20. Shoaib, N.F.; Ain, Q.U.; Iqbal, K.; Asif, M. Effect of ablution on Methicillin-resistant Staphylococcus aureus (MRSA) nasal colonisation in healthcare workers. J. Pak. Med. Assoc. 2021, 71, 1472-1475. [CrossRef] [PubMed]

21. Zhu, F.; Zhuang, H.; Ji, S.; Xu, E.; Di, L.; Wang, Z.; Jiang, S.; Wang, H.; Sun, L.; Shen, P.; et al. Household transmission of community-associated Methicillin-resistant Staphylococcus aureus. Front. Public Health 2021, 31, 658638. [CrossRef] [PubMed]

22. Reygaert, W.C. An overview of the antimicrobial resistance mechanisms of bacteria. AIMS Microbiol. 2018, 26, 482-501. [CrossRef] [PubMed]

23. Megged, O. Coagulase-negative staphylococci: A rare cause of urinary tract infections in children with consequences on clinical practice. Eur. J. Pediatr. 2021, 4, 1-6. [CrossRef] [PubMed]

24. Heilbronner, S.; Foster, T.J. Staphylococcus lugdunensis: A skin commensal with invasive pathogenic potential. Clin. Microbiol. Rev. 2020, 23, e00205-20. [CrossRef] [PubMed]

25. Becker, K.; Heilmann, C.; Peters, G. Coagulase-negative staphylococci. Clin Microbiol Rev. 2014, 27, 870-926. [CrossRef] [PubMed]

26. Asante, J.; Hetsa, B.A.; Amoako, D.G.; Abia, A.L.K.; Bester, L.A.; Essack, S.Y. Multidrug-resistant coagulase-negative staphylococci isolated from bloodstream in the uMgungundlovu District of KwaZulu-Natal Province in South Africa: Emerging pathogens. Antibiotics 2021, 18, 198. [CrossRef]

27. Khajuria, A.; Praharaj, A.K.; Kumar, M.; Grover, N. Carbapenem resistance among Enterobacter species in a tertiary care hospital in central India. Chemother. Res. Pract. 2014, 2014, 972646. [CrossRef] [PubMed]

28. Yahav, D.; Giske, C.G.; Grāmatniece, A.; Abodakpi, H.; Tam, V.H.; Leibovici, L. New $\beta$-Lactam- $\beta$-Lactamase inhibitor combinations. Clin. Microbiol. Rev. 2020, 11, e00115-20. [CrossRef]

29. Arendrup, M.C.; Patterson, T.F. Multidrug-resistant Candida: Epidemiology, molecular mechanisms, and treatment. J. Infect. Dis. 2017, 15 (Suppl. 3), 445-451. [CrossRef] [PubMed]

30. Lee, Y.; Puumala, E.; Robbins, N.; Cowen, L.E. Antifungal drug resistance: Molecular mechanisms in Candida albicans and Beyond. Chem. Rev. 2021, 24, 3390-3411. [CrossRef]

31. Apeh, V.O.; Njoku, O.U.; Nwodo, F.O.C.; Chukwuma, I.F.; Emmanuel, A.A. In silico drug-like properties prediction and in vivo antifungal potentials of Citrullus lanatus seed oil against Candida albicans. Arab. J. Chem. 2022, 15, 103578. [CrossRef]

32. Bourbeau, K.; Gupta, S.; Wang, S. Candida albicans meningitis in AIDS patient: A case report and literature review. IDCases 2021, 25, e01216. [CrossRef] [PubMed]

33. Spettel, K.; Bumberger, D.; Camp, I.; Kriz, R.; Willinger, B. Efficacy of octenidine against emerging echinocandin-, azole- and multidrug-resistant Candida albicans and Candida glabrata. J. Glob. Antimicrob. Resist. 2022, in press. [CrossRef] [PubMed]

34. Küçükgüzel, S.G.; Mazi, A.; Sahin, F.; Öztürk, S.; Stables, J. Synthesis and biological activities of diflunisal hydrazide-hydrazones. Eur. J. Med. Chem. 2003, 38, 1005-1013. [CrossRef]

35. Metwally, K.A.; Abdel-Aziz, L.M.; Lashine, E.S.M.; Husseiny, M.I.; Badawy, R.H. Hydrazones of 2-aryl-quinoline-4-carboxylic acid hydrazides: Synthesis and preliminary evaluation as antimicrobial agents. Bioorg. Med. Chem. 2006, 14, 8675-8682. [CrossRef] [PubMed]

36. Haiba, N.S.; Khalil, H.H.; Moniem, M.A.; El-Wakil, M.H.; Bekhit, A.A.; Khattab, S.N. Design, synthesis and molecular modeling studies of new series of s-triazine derivatives as antimicrobial agents against multi-drug resistant clinical isolates. Bioorg. Chem. 2019, 89, 103013. [CrossRef] [PubMed]

37. Backes, G.L.; Neumann, D.M.; Jursic, B.S. Synthesis and antifungal activity of substituted salicylaldehyde hydrazones, hydrazides and sulfohydrazides. Bioorg. Med. Chem. 2014, 22, 4629-4636. [CrossRef] [PubMed]

38. Savini, L.; Chiasserini, L.; Gaeta, A.; Pellerano, C.; Moro, V.A. Synthesis and Anti-tubercular Evaluation of 4-Quinolylhydrazones. Bioorg. Med. Chem. 2002, 10, 2193-2198. [CrossRef]

39. Vicini, P.; Incerti, M.; Doytchinova, I.A.; La Colla, P.; Busonera, B.; Loddo, R. Synthesis and antiproliferative activity of benzo[d]isothiazole hydrazones. Eur. J. Med. Chem. 2006, 41, 624-632. [CrossRef] [PubMed]

40. Mohareb, R.M.; Fleita, D.H.; Sakka, O.K. Novel synthesis of hydrazide-hydrazone derivatives and their utilization in the synthesis of coumarin, pyridine, thiazole and thiophene derivatives with antitumor activity. Molecules 2011, 16, 16-27. [CrossRef] [PubMed]

41. Joshi, S.D.; Vagdevi, H.M.; Vaidya, V.P.; Gadaginamath, G.S. Synthesis of new 4-pyrrol-1-yl benzoic acid hydrazide analogs and some derived oxadiazole, triazole and pyrrole ring systems: A novel class of potential antibacterial and antitubercular agents. Eur. J. Med. Chem. 2008, 43, 1989-1996. [CrossRef] 
42. Joshi, S.D.; More, U.A.; Pansuriya, K.; Aminabhavi, T.M.; Gadad, A.K. Synthesis and molecular modeling studies of novel pyrrole analogs as antimycobacterial agents. J. Saudi Chem. Soc. 2017, 21, 42-57. [CrossRef]

43. Rollas, S.; Gulerman, N.; Erdeniz, H. Synthesis and antimicrobial activity of some new hydrazones of 4-fluorobenzoic acid hydrazide and 3-acetyl-2,5-disubstituted-1,3,4-oxadiazolines. Farmaco 2002, 57, 171-174. [CrossRef]

44. Dewangan, D.; Pandey, A.; Sivakumar, T.; Rajavel, R.; Dubey, R.D. Synthesis of some novel 2, 5-disubstituted 1, 3, 4-oxadiazole and its analgesic, anti-inflammatory, anti-bacterial and anti-tubercular activity. Int. J. ChemTech Res. 2010, 2, $1397-1412$.

45. Koçyiğit-Kaymakçığlu, B.; Oruç-Emre, E.E.; Ünsalan, S.; Tabanca, N.; Khan, S.I.; Wedge, D.E.; İşcan, G.; Demirci, F.; Rolla, S. Synthesis and biological activity of hydrazide-hydrazones and their corresponding 3-Acetyl-2,5-disubstituted-2,3-dihydro-1,3,4oxadiazoles. Med. Chem. Res. 2012, 21, 3499-3508. [CrossRef]

46. Jadhav, G.R.; Deshmukh, D.G.; Medhane, V.J.; Gaikwad, V.B.; Bholay, A.D. 2,5-Disubstituted 1,3,4-oxadiazole derivatives of chromeno[4,3-b]pyridine: Synthesis and study of antimicrobial potency. Heterocycl. Commun. 2016, 22, 123-130. [CrossRef]

47. Jin, L.; Chen, J.; Song, B.; Chen, Z.; Yang, S.; Li, Q.; Hu, D.; Xu, R. Synthesis, structure, and bioactivity of $\mathrm{N}^{\prime}$-substituted benzylidene-3,4,5-trimethoxybenzohydrazide and 3-acetyl-2-substituted phenyl-5-(3,4,5-trimethoxyphenyl)-2,3-dihydro-1,3,4oxadiazole derivatives. Bioorg. Med. Chem. Lett. 2006, 16, 5036-5040. [CrossRef] [PubMed]

48. Salum, L.B.; Mascarello, A.; Canevarolo, R.R.; Altei, W.F.; Laranjeira, A.B.A.; Neuenfeldt, P.D.; Stumpf, T.R.; Chiaradia-Delatorre, L.D.; Vollmer, L.L.; Daghestani, H.N.; et al. N-(1'-naphthyl)-3,4,5-trimethoxybenzohydrazide as microtubule destabilizer: Synthesis, cytotoxicity, inhibition of cell migration and in vivo activity against acute lymphoblastic leukemia. Eur. J. Med. Chem. 2015, 96, 504-518. [CrossRef]

49. Pasqualoto, K.F.M.; Ferreira, E.I.; Santos-Filho, O.A.; Hopfinger, A.J. Rational design of new antituberculosis agents: Receptorindependent four-dimensional quantitative structure-activity relationship analysis of a set of isoniazid derivatives. J. Med. Chem. 2004, 47, 3755-3764. [CrossRef] [PubMed]

50. Baquero, E.; Quiñones, W.; Ribon, W.; Caldas, M.L.; Sarmiento, L.; Echeverri, F. Effect of an Oxadiazoline and a Lignan on Mycolic Acid Biosynthesis and Ultrastructural Changes of Mycobacterium tuberculosis. Tuberc. Res. Treat. 2011, 2011, 1-6. [CrossRef]

51. Kyme, P.; Thoennissen, N.H.; Tseng, C.W.; Thoennissen, G.B.; Wolf, A.J.; Shimada, K.; Krug, U.O.; Lee, K.; Müller-Tidow, C.; Berdel, W.E.; et al. C/EBP $\varepsilon$ mediates nicotinamide-enhanced clearance of Staphylococcus aureus in mice. J. Clin. Investig. 2012, 122, 3316-3329. [CrossRef]

52. Trott, O.; Olson, A.J. AutoDock Vina: Improving the speed and accuracy of docking with a new scoring function, efficient optimization, and multithreading. J. Comput. Chem. 2009, 31, 455-461. [CrossRef]

53. Olender, D.; Żwawiak, J.; Zaprutko, L. Multidirectional efficacy of biologically active nitro compounds included in medicines. Pharmaceuticals 2018, 11, 54. [CrossRef]

54. Bot, C.; Hall, B.S.; Álvarez, G.; Di Maio, R.; González, M.; Cerecetto, H.; Wilkinsona, S.R. Evaluating 5-nitrofurans as trypanocidal agents. Antimicrob. Agents Chemother. 2013, 57, 1638-1647. [CrossRef] [PubMed]

55. Race, P.R.; Lovering, A.L.; Green, R.M.; Ossor, A.; White, S.A.; Searle, P.F.; Wrighton, C.J.; Hyde, E.I. Structural and mechanistic studies of Escherichia coli nitroreductase with the antibiotic nitrofurazone: Reversed binding orientations in different redox states of the enzyme. J. Biol. Chem. 2005, 280, 13256-13264. [CrossRef]

56. Reeve, S.M.; Scocchera, E.; Ferreira, J.J.; G-Dayanandan, N.; Keshipeddy, S.; Wright, D.L.; Anderson, A.C. Charged propargyllinked antifolates reveal mechanisms of antifolate resistance and inhibit trimethoprim-resistant MRSA strains possessing clinically relevant mutations. J. Med. Chem. 2016, 59, 6493-6500. [CrossRef] [PubMed]

57. Breijyeh, Z.; Jubeh, B.; Karaman, R. Resistance of Gram-negative bacteria to current antibacterial agents and approaches to resolve it. Molecules 2020, 16, 1340. [CrossRef]

58. Paruch, K.; Popiołek, Ł.; Wujec, M. Antimicrobial and antiprotozoal activity of 3-acetyl-2,5-disubstituted-1,3,4-oxadiazolines: A review. Med. Chem. Res. 2020, 29, 1-16. [CrossRef]

59. Popiołek, Ł.; Biernasiuk, A.; Paruch, K.; Malm, A.; Wujec, M. Synthesis and in Vitro Antimicrobial Activity Screening of New 3-Acetyl-2,5-disubstituted-1,3,4-oxadiazoline Derivatives. Chem. Biodivers. 2019, 16, e1900082. [CrossRef] [PubMed]

60. Paruch, K.; Popiołek, Ł.; Biernasiuk, A.; Berecka-rycerz, A.; Malm, A.; Gumieniczek, A.; Wujec, M. Novel derivatives of 4-methyl1,2,3-thiadiazole-5-carboxylic acid hydrazide: Synthesis, lipophilicity, and in vitro antimicrobial activity screening. Appl. Sci. 2021, 11, 1180. [CrossRef]

61. Popiołek, Ł.; Piątkowska-Chmiel, I.; Gawrońska-Grzywacz, M.; Biernasiuk, A.; Izdebska, M.; Herbet, M.; Sysa, M.; Malm, A.; Dudka, J.; Wujec, M. New hydrazide-hydrazones and 1,3-thiazolidin-4-ones with 3-hydroxy-2-naphthoic moiety: Synthesis, in vitro and in vivo studies. Biomed. Pharmacother. 2018, 103, 1337-1347. [CrossRef] [PubMed]

62. Popiołek, Ł.; Biernasiuk, A.; Berecka, A.; Gumieniczek, A.; Malm, A.; Wujec, M. New hydrazide-hydrazones of isonicotinic acid: Synthesis, lipophilicity and in vitro antimicrobial screening. Chem. Biol. Drug Des. 2018, 91, 915-923. [CrossRef] [PubMed]

63. European Committee for Antimicrobial Susceptibility Testing (EUCAST) of the European Society of Clinical Microbiology and Infectious Diseases (ESCMID). Determination of minimum inhibitory concentrations (MICs) of antibacterial agents by broth dilution. Clin. Microbiol. Inf. Dis. 2003, 9, 9-15.

64. CLSI Standard M27; Reference Method for Broth Dilution Antifungal Susceptibility Testing of Yeasts. 4th ed. Clinical and Laboratory Standards Institute (CLSI): Wayne, PA, USA, 2017. 